FGV EBAPE

ESCOLA BRASILEIRA DE ADMINISTRAÇÃO PÚBLICA E DE EMPRESAS
Programa de Pesquisa em Gestão da Aprendizagem Tecnológica e Inovação Industrial no Brasil, da EBAPE/FGV

Technological Learning and Industrial Innovation Working Paper Series

\title{
Acumulação de Capacidades Tecnológicas para Inovação e Fortalecimento da Competitividade no Ecossistema de Biotecnologia para Saúde Humana no Brasil
}

\author{
Paulo N. Figueiredo \\ Daniela Uziel \\ Bernardo Cabral \\ Lohanna Palhinha \\ Pedro Ivo Gomes
}




\title{
Acumulação de Capacidades Tecnológicas para Inovação e Fortalecimento da Competitividade no Ecossistema de Biotecnologia para Saúde Humana no Brasil ${ }^{1}$
}

\author{
Paulo N. Figueiredo \\ Professor Titular EBAPE/FGV \\ Daniela Uziel \\ Professora Associada UFRJ \\ Bernardo Cabral \\ Professor Adjunto UFBA \\ Lohanna Palhinha \\ Assistente de Pesquisa EBAPE/FGV \\ Pedro Ivo Gomes \\ Assistente de Pesquisa EBAPE/FGV
}

${ }^{1}$ Trata-se de um artigo preliminar sobre pesquisa em andamento, desenvolvida no âmbito do Programa de Pesquisa em Aprendizagem Tecnológica e Inovação Industrial no Brasil, da EBAPE/FGV. Os autores agradecem os estagiários João Luiz Vianna, Lucas de Jesus Lima e Grazielle Lima Silva pela sua colaboração no desenvolvimento da pesquisa. 


\section{Resumo}

Este documento apresenta uma versão parcial do estudo em desenvolvimento sobre o processo de acumulação de capacidades tecnológicas para atividades de produção e de inovação, suas fontes e impactos na performance competitiva, em nível de empresas, no setor de biotecnologia para saúde humana no Brasil. Considerando a alta importância estratégica dessas indústrias para a economia brasileira, a sua capacidade para inovar e competir internacionalmente impacta diretamente no grau e extensão do desenvolvimento socioeconômico do Brasil. A despeito da quantidade de estudos sobre essas indústrias no Brasil, há uma enorme escassez de evidências e explicações sistematizadas e dinâmicas, com adequado grau de detalhe e profundidade, em nível intraindústria e empresarial, que possam iluminar e suportar o desenho e a implementação de políticas públicas aliadas a estratégias empresariais orientadas ao fortalecimento das capacidades tecnológicas inovadoras e da competitividade internacional dessas indústrias no Brasil. Baseando-se em uma metodologia inovadora, validada cientificamente, em nível internacional, e utilizada largamente no exame de outras indústrias intensivas em processo no Brasil, a pesquisa aqui proposta objetiva: (a) Gerar novas evidências e explicações sobre o processo de acumulação de capacidades tecnológicas, suas fontes e seus impactos em atividades inovadoras e indicadores de competitividade, com base em evidências de empresas selecionadas das indústrias farmoquímica e farmacêutica voltadas para saúde humana no Brasil. As evidências serão coletadas e examinadas em nível de empresas e de forma anonimizada e os dados da pesquisa, embora em nível micro e intraindústria, serão tratados de forma agregada; (b) Gerar insumos e suporte para o desenho, redesenho e/ou aprimoramento de políticas públicas aliadas a estratégias empresariais orientadas ao fortalecimento da competitividade internacional da indústria farmacêutica e farmoquímica no Brasil. Considerando que inovação e fortalecimento da competitividade são processos, esta pesquisa, quando concretizada, terá o potencial para estimular esforços para a construção de um sistema de monitoramento contínuo de indicadores de inovação e competitividade dessas indústrias no Brasil, com base nas evidências, análises e metodologia da pesquisa.

Palavras chave: Capacidade Tecnológica, Aprendizagem Tecnológica, Inovação, Biotecnologia, Saúde Humana 


\begin{abstract}
This document presents a partial version of the study in progress on the process of accumulation of technological capabilities for production and innovation activities, its sources and impacts on competitive performance, at the company level, in the biotechnology sector for human health in Brazil. Considering the high strategic importance of these industries for the Brazilian economy, their ability to innovate and compete internationally has a direct impact on the degree and extent of socioeconomic development in Brazil. Despite the number of studies on these industries in Brazil, there is a huge lack of systematic and dynamic evidence and explanations, with an adequate degree of detail and depth, at an intraindustry and business level that can illuminate and support the design and implementation of public policies combined with business strategies aimed at strengthening innovative technological capabilities and the international competitiveness of these industries in Brazil. Based on an innovative methodology, scientifically validated at an international level, and widely used in the examination of other process-intensive industries in Brazil, the research proposed here aims to: (a) Generate new evidence and explanations about the process of capacity accumulation technologies, their sources and their impacts on innovative activities and competitiveness indicators, based on evidence from selected companies in the pharmochemical and pharmaceutical industries in Brazil. Evidence will be collected and examined at the company level and anonymously and the survey data, although at the micro and intra-industry level, will be treated in an aggregated way. (b) Generate inputs and support for the design, redesign and/or improvement of public policies combined with business strategies aimed at strengthening the international competitiveness of the pharmaceutical and pharmochemical industry in Brazil. Considering that innovation and strengthening competitiveness are processes, this research, if carried out, would have the potential to stimulate efforts to build a continuous monitoring system for indicators of innovation and competitiveness in these industries in Brazil, based on evidence, analysis and methodology of the research.
\end{abstract}

Keywords: Technological Capability, Technological Learning, Innovation, Biotechnology, Human Health 


\section{Introdução}

Com uma população de mais de 210 milhões, o Brasil é o único país com população superior a 200 milhões de habitantes a oferecer um sistema público de saúde gratuito - o SUS - de caráter universalista, sob a ideia de que a saúde é um direito social, conforme a Constituição Federal de 1988. Ao longo das últimas décadas, em função, em grande parte, do crescimento e do envelhecimento da população brasileira, bem como do aumento de sua expectativa de vida, de suas alterações epidemiológicas e das inovações nas indústrias farmoquímica e farmacêutica em nível global, tem havido pressões enormes e crescentes sobre a demanda e oferta de medicamentos biotecnológicos que, por sua vez, pressionam os gastos públicos.

As mudanças na estrutura industrial e nas cadeias de fornecimento, tanto em nível nacional como internacional, assim como as escolhas feitas por certos países, têm levado a uma dependência de aproximadamente $85 \%$ a $90 \%$ de importação de insumos farmacêuticos ativos (IFA) da Índia e da China. Também tem havido enorme dependência do Brasil da importação de países avançados dos medicamentos biológicos para atender às crescentes demandas internas.

\subsection{Os impactos da dependência externa como reflexo na balança comercial}

No Brasil, essas altas taxas de dependência se refletem na balança comercial das indústrias de insumos farmacêuticos e biofarmacêuticos, assim como na balança comercial do país:

- Em 2013, enquanto as exportações da cadeia produtiva farmacêutica no Brasil atingiram US\$2,0 bilhões, as importações atingiram US\$ 9,7 bilhões. Isto representa um aumento do déficit comercial neste setor de $15 \%$ em relação ao ano anterior (ABIQUIFI, 2013).

- Caem os investimentos públicos no setor, crescem os gastos com a importação de remédios, vacinas e insumos farmacêuticos.

- A balança comercial atingiu em 2018 e 2019 recorde negativo histórico de US\$ 7 bilhões, segundo o Ministério da Economia. Foram US\$ 8+ bilhões em importações e US\$1,2 bilhão em exportações em 2018. 


\subsection{Impactos e medidas no pós-COVID-19}

A crise derivada da pandemia COVID-19 tem agravado ainda mais essa situação. Num cenário pós-COVID-19 e/ou de convivência com ela ('novo normal'), tem havido debates e movimentos internacionais para a reorganização das estruturas industriais e cadeias globais de fornecimento para diminuição da dependência de países ocidentais ao fornecimento da China e Índia.

Ao mesmo tempo, o debate internacional considera alternativas de fortalecimento da capacidade de produção e sistemas de inovação locais no campo de insumos de medicamentos. Também se discutem estratégias híbridas, como a assim-chamada 'China +1 '. Porém, tratam-se de decisões complexas que exigem um detalhado grau de evidências e alinhamentos entre políticas públicas e estratégias empresariais de curto, médio e longo prazos.

Mas como o Brasil tem enfrentado essa situação e como tem se preparado para esses novos cenários? O Brasil encontra-se em uma encruzilhada.

De um lado, ao longo das últimas décadas e, com maior intensidade, ao longo dos últimos anos, tem havido baixa capacidade do Estado de implementar políticas eficazes e sustentáveis para a promoção local de medicamentos (por exemplo, a utilização do poder de compra do governo e a promoção de parcerias produtivas público-privado). Ao mesmo tempo, a indústria, por razões diversas, não tem se motivado à ampliação da produção e atividades de inovação no campo dos medicamentos farmacêuticos e dos medicamentos biológicos em nível local.

Por outro lado, a despeito da existência de vários estudos e debates sobre essa indústria em nível agregado (nível macro), há uma enorme escassez de evidências sobre as indústrias farmacêutica e farmoquímica focadas em saúde humana no Brasil, em nível de empresas, em termos de sua real capacidade tecnológica para atividades de produção e de inovação e seus impactos na competitividade (ou performance competitiva).

\subsection{Por que os estudos e abordagens existentes não são suficientes?}

As evidências que existem sobre desenvolvimento de capacidades tecnológicas e inovação nas indústrias farmacêutica e farmoquímica no Brasil tendem a ser muito agregadas 
e baseadas em surveys, como é o caso da PINTEC/IBGE. Esse modelo de avaliação apenas mostra o grau de novidade, de forma binária, como "inovadora" ou "não inovadora". As evidências provenientes desse tipo de surveys apontam a necessidade de:

(1) Implementação de estudo em nível intraindústria e em nível de empresas (meso e micro), com adequado grau de detalhe e profundidade sobre o real processo de acumulação de capacidades tecnológicas, suas fontes e impactos nessas indústrias;

(2) Fortalecimento da capacidade inovadora e competitiva dessas indústrias no Brasil. Para isso, porém, torna-se fundamental a geração de evidências adequadas.

É por meio das suas capacidades tecnológicas, que significam um estoque de recursos a base de capital humano, sistemas técnico-físicos e sistema organizacional (processos, rotinas), que as empresas (e o país) realizam suas atividades de produção e de inovação.

É por meio de atividades inovadoras, de vários tipos e níveis, que as empresas e startups agregam valor e novidade a produtos, serviços e processos, assim como aumentam a produtividade e ganham novos mercados, locais e globais (ou seja, competitividade). Por isso, é fundamental o conhecimento sobre o real processo de acumulação de capacidades tecnológicas, para produção e inovação, em nível de empresas e em nível intraindústria, bem como suas fontes e impactos.

\subsection{Questões e foco da pesquisa}

A pesquisa aqui proposta objetiva gerar novas evidências e explicações sobre o processo de Acumulação de Capacidades Tecnológicas (ACT), em nível de empresas, suas causas e consequências, nas indústrias farmacêutica e biofarmacêutica e nas startups e empresas de biotecnologia para saúde humana no Brasil. Ao mesmo tempo, a pesquisa objetiva gerar insumos e recomendações práticas para o desenho, redesenho e/ou aprimoramento de políticas públicas e ações empresariais orientadas ao desenvolvimento tecnológico e fortalecimento da competitividade no setor de biotecnologia para saúde humana no Brasil. 


\section{Base Conceitual}

A base conceitual que dá sustentação a esta pesquisa envolve o exame da relação entre a acumulação de capacidades tecnológicas (para atividades de produção e inovação), os mecanismos subjacentes de aprendizagem (fontes para acumulação de capacidades tecnológicas) e os impactos gerados em termos de competitividade à luz de mudanças na moldura institucional.

\subsection{A perspectiva sobre inovação nesta pesquisa}

Antes de apresentar a base analítica do projeto e definir seus principais componentes, é importante esclarecer a ideia sobre inovação que permeia esta pesquisa, a qual transcende as perspectivas limitadas que tratam a inovação somente como atividades altamente complexas derivadas de esforço científico em sofisticados laboratórios de P\&D. Como mostrado na Figura 1, uma ampla ideia de inovação abrange a implementação de mudanças em produtos/serviços, processos e sistemas organizacionais e gerenciais - da iniciação à adaptação menor e daí até os estágios mais avançados. As atividades incluem imitação duplicativa, imitação criativa e as mais sofisticadas ações de design e desenvolvimento à base de engenharia e P\&D (Figura 1). Essas atividades podem ter graus de novidade que variam de novas para a empresa a novas para a economia, como também para o mercado internacional. 
Figura 1: Escala de tipos e graus de inovação a ser usada na pesquisa

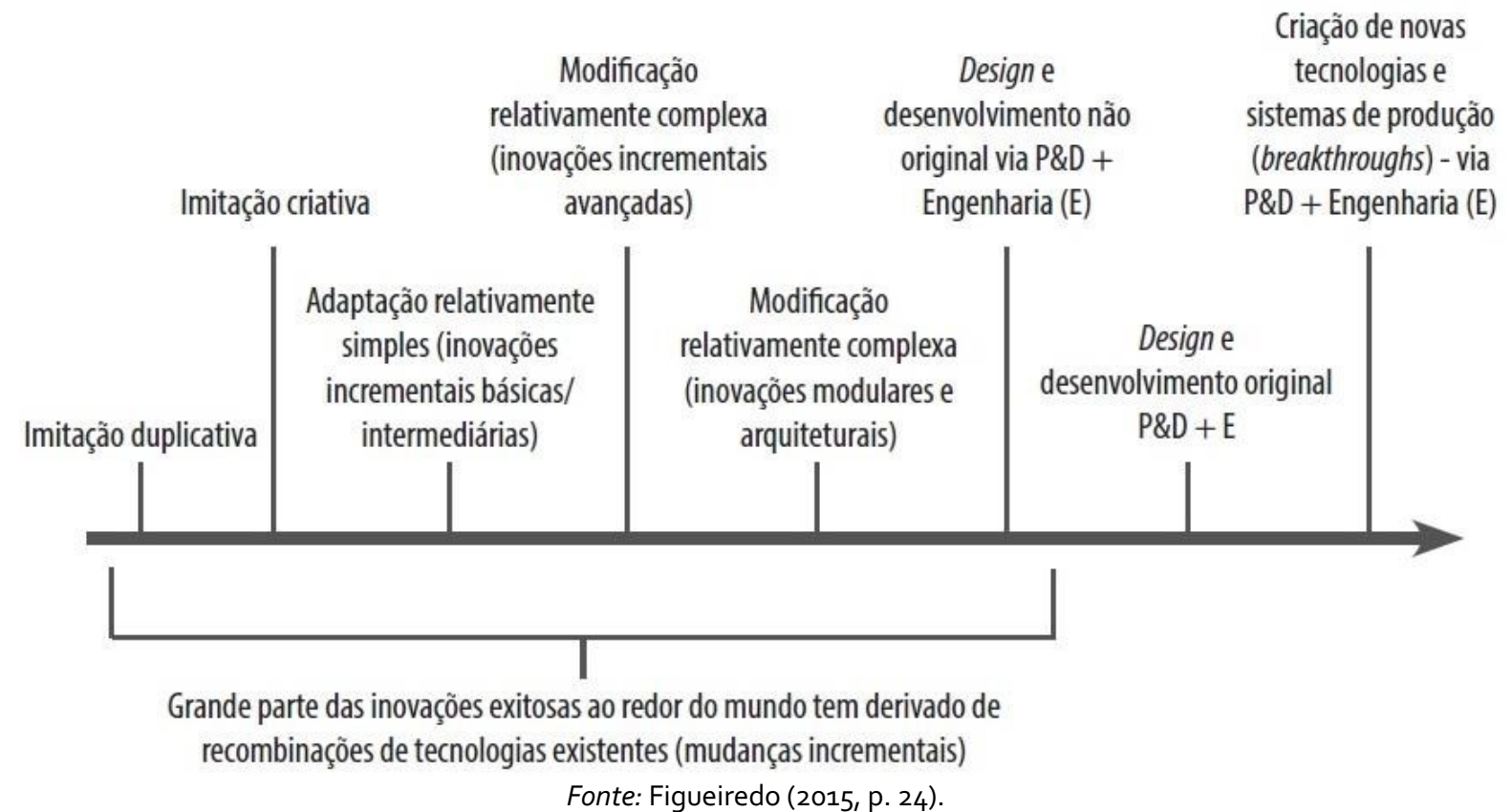

Fonte: Figueiredo (2015, p. 24).

A Figura 1 sugere que a ideia de classificar empresas (ou países), segundo uma perspectiva "binária", como "inovadora" versus "não inovadora" é limitada e equivocada. Aliás, a perspectiva de inovação como um contínuo de atividades com crescentes graus de complexidade e novidade é particularmente importante para a compreensão do processo de inovação em empresas que operam em economias em desenvolvimento e emergentes. Várias dessas empresas iniciam suas atividades tecnológicas com base em imitação duplicativa, para poderem avançar ao outro extremo do espectro da Figura 1.

Dessa forma, a visão de inovação da pesquisa é abrangente e não se limita à alta tecnologia de fronteira, mesmo se tratando de um setor altamente tecnológico como é o caso da biotecnologia, e pode derivar de uma forte base de engenharia nas empresas como é típico, por exemplo, das indústrias de máquinas alemães, líderes globais em vários segmentos - e até mesmo do chão de fábrica, de uma sólida ferramentaria capaz de fazer modificações básicas em produtos e processos. Inovação é entendida, assim, como processo e não como evento isolado, muito menos "linha de chegada".

Não se pense, porém, que a ênfase nesse espectro de estágios de capacidade tecnológica e inovadora significa, de alguma forma, negligenciar as etapas superiores de $P \& D$ e os rankings patentários. É exatamente o contrário. O problema é que a visão, por vezes predominante, de enfatizar somente o desenvolvimento de capacidades nos estágios 
superiores fracassa exatamente por dar pouca atenção à massa crítica das fases anteriores, que compõem o tipo de tecido produtivo em que é possível surgir com mais frequência os expoentes de fronteira.

\subsection{Apresentação da base analítica da pesquisa}

O modelo analítico do projeto está representado na Figura 2, a seguir. Esse modelo é importante para fornecer avanços em termos de novo entendimento sobre a relação entre as questões estudadas, assim como um claro esclarecimento às autoridades públicas sobre as diferenças e semelhanças entre as empresas, no que diz respeito às causas e resultados da formação de capacidade de inovação e competitividade. Isso é importante para adaptar suas políticas e estratégias de negócios.

Figura 2: Modelo analítico da pesquisa

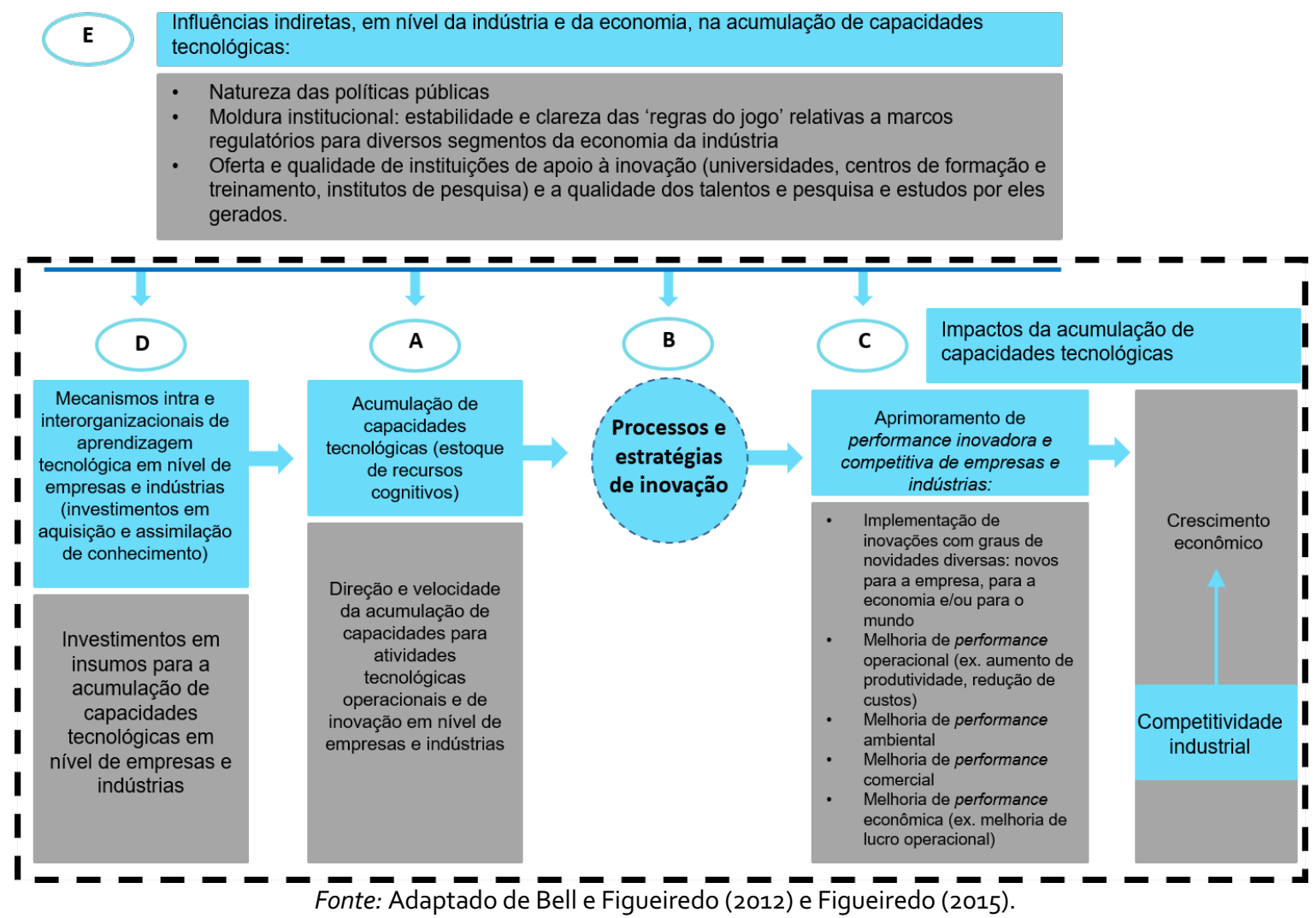

Esse conjunto de relações representado na Figura 2 será analisado como um conjunto de setores industriais e suas principais empresas produtoras, neste caso composta por empresas estabelecidas de todos os portes e startups, como também organizações de 
apoio à inovação, como universidades, habitats de inovação e institutos de pesquisa. Destaca-se que esta pesquisa dará atenção especial aos inputs, isto é, aos fatores que levam a inovar, e não apenas ao output (inovação em si). Entretanto, o foco recai sobre as relações existentes entre as etapas $A, C$ e $D$, diretamente relacionadas aos processos e estratégias de inovação da etapa B. As influências indiretas em nível de indústria e economia apresentadas na etapa E são levadas em consideração, principalmente na elaboração de insights sobre políticas públicas, apesar de não integrarem o método estatístico de mensuração das relações entre as etapas para startups e empresas estabelecidas, conforme destacado anteriormente, porém por constituírem relevantes infraestruturas existente em universidades e centros de pesquisa importantes para a geração de conhecimento existente no país, o estudo considera que exista expressiva quantidade de institutos de pesquisas relacionados à saúde humana, ainda não definidos, mas já identificado que os estados do Rio Grande do Sul, Santa Catarina, Paraná, São Paulo, Minas Gerais, Rio de Janeiro e Pernambuco possuem centros de pesquisa cuja infraestruturas podem servir como importante suporte ao desenvolvimento de conhecimentos relacionados à biotecnologia para saúde humana, portanto, serão analisados e considerados como potencial influência indireta, classificados como oferta e qualidade de instituições de apoio à inovação, conforme modelo analítico.

A: acumulação de capacidades tecnológicas. Capacidades tecnológicas são definidas aqui como os recursos (base de conhecimento) para administrar e gerar as mudanças tecnológicas. Envolvem o capital humano, que não se limita a cientistas com pósdoutorado, mas pode incluir engenheiros, técnicos e até pessoal de "chão de fábrica"; o capital físico, representado por laboratórios, bancos de dados, software etc.; e o capital organizacional, que inclui processos organizacionais, procedimentos e rotinas. Com relação às capacidades tecnológicas, fez-se distinção entre aquelas voltadas à operação (ou produção) e à inovação.

As capacidades tecnológicas operacionais (ou de produção) referem-se àquelas que permitem às empresas usar ou adotar tecnologias e sistemas de produção existentes, ou seja, são os recursos necessários para realizar atividades de produção de bens ou serviços com dado grau de eficiência e também em processos biotecnológicos altamente sofisticados. Já as capacidades tecnológicas inovadoras possibilitam às empresas 
implementar diferentes tipos e graus de atividades inovadoras, estando relacionadas aos recursos necessários para gerar e gerir mudanças tecnológicas, em termos de inovações em processos, produtos, sistemas técnico-físicos, serviços e organização. Dessas capacidades provém a diferença, por exemplo, entre uma empresa capaz de manufaturar um celular e outra que, além de fabricar, pode desenvolver o software do aparelho móvel; entre uma empresa que monta automóveis e outra capaz de projetá-los; ou entre um país com capacidade tecnológica para lançar foguetes, mesmo tendo uma renda baixa, como a Índia, e outro que não tem a mesma capacidade, como o Brasil.

Reitera-se ser importante distinguir entre uma operação avançada tecnologicamente, como no caso de uma empresa que opera maquinário ou sistema de produção de última geração, e atividades que alteram, inovam ou criam novas tecnologias e sistemas de produção. A realização de cada uma dessas atividades tecnológicas implica a acumulação de capacidades distintas em empresas e indústrias. Consequentemente, os investimentos empresariais - e as políticas públicas - relativos ao desenvolvimento de capacidades tecnológicas operacionais e de inovação são significativamente diferentes.

Para medir os tipos e níveis de capacidade das empresas, este projeto trabalhou com uma escala de estágios de capacidade tecnológica, importante para entender até que ponto e como empresas, startups e indústrias estão se movendo ao longo desse gradiente. Um dos principais objetivos de políticas públicas que venham a se valer do tipo de conhecimento obtido com este projeto pode perfeitamente ser a evolução do Brasil para um elevado nível patentário e de concentração de laboratórios de P\&D (o lado extremo direito da Figura 1). Contudo, para que se caminhe nessa direção, é indispensável entender como as próprias empresas comportam-se nessa trilha.

Especificamente, o projeto empregará uma abordagem comprovada e adotada nos estudos de formação de capacidade das empresas de economias emergentes, a qual tem como fundamento a aquisição direta de informações descritivas sobre as atividades tecnológicas dessas empresas. Em outras palavras, terá como base evidências sobre as atividades que as empresas e startups são, de fato, capazes de realizar tecnologicamente, individualmente e/ou em parceria. Especificamente para o caso das startups, o estudo tomará como premissa de capacidade revelada os produtos e/ou serviços biotecnológicos já introduzidos no mercado, resultantes das atividades tecnológicas que esse 
tipo de organização é capaz de desenvolver. Porém, considerada a característica de incerteza que é intrínseca a esse tipo de organização, startups que ainda estão nas etapas que precedem a introdução de suas soluções no mercado terão correlacionadas as principais dificuldades ou entraves que precisam ser superados para atingirem o êxito da inovação, e tais condições poderão ser consideradas "capacidades latentes" por ainda estarem na etapa de invenção. Tais informações servirão como importantes insumos para políticas públicas e estratégias empresariais cruciais para o fortalecimento do ecossistema de inovação relacionado à biotecnologia para saúde humana no Brasil. A partir dessas informações, diversos procedimentos subsequentes serão utilizados para classificar as atividades tecnológicas das empresas e startups em níveis sucessivos de complexidade e novidade, podendo-se, com isso, inferir seus níveis de capacidade tecnológica à luz da escala da Figura 3 .

Essa classificação normalmente envolve sequências que se iniciam nos níveis de capacidade de produção até os níveis de capacidade inovadora. A Figura 3 fornece um exemplo ilustrativo que faz distinção entre quatro níveis de capacidade inovadora (integrando os tecnológicos e organizacionais), abrangendo das capacidades inovadoras básicas (para adaptações menores, etc.) até a capacidade inovadora no âmbito de liderança mundial, para superação dos líderes globais. Esse modelo será utilizado para coletar evidências e analisar a natureza das trajetórias e a razão pela qual as startups e empresas estudadas caminham pelos diferentes níveis de capacidade. A escala da Figura 3 alinha-se à perspectiva ampliada de inovação representada na Figura 1. 
Figura 3: Escala de níveis de capacidade tecnológica

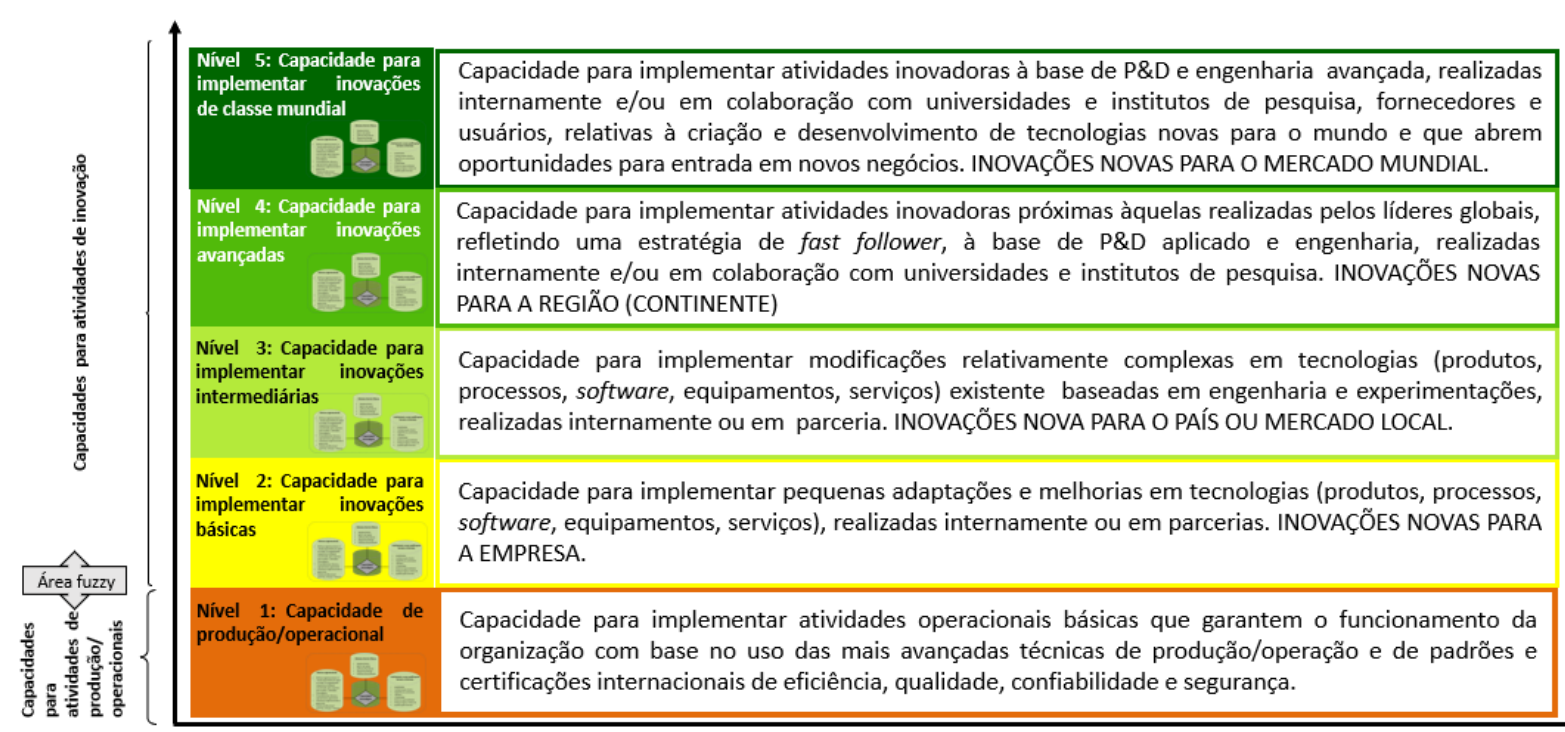

Fonte: Figueiredo (2019).

Linha de tempo

A fim de evitar análises de natureza "subjetiva" acerca dos níveis de capacidade tecnológica alcançados pelas empresas e startups em estudo, a avaliação com base na escala da Figura 3 será substanciada por evidências concretas (fatos) que comprovem se a empresa é capaz ou não de realizar certa atividade tecnológica, com determinado grau de novidade e complexidade. Com relação a essa taxonomia para medição de capacidades tecnológicas, é relevante esclarecer que: (i) ela não pressupõe que todas as unidades de uma mesma empresa necessariamente se capacitam em uma sequência linear; (ii) tampouco pressupõe que as capacidades são acumuladas e sustentadas (ou debilitadas) ao mesmo tempo e à mesma velocidade para as diferentes funções tecnológicas; (iii) para certa função ou área tecnológica (por exemplo, processo, produto), pode-se alcançar uma profundidade de capacidade tecnológica, enquanto, para outra, um nível mais superficial; (iv) é possível uma empresa acumular partes de certas capacidades inovadoras, sem que a acumulação de suas capacidades operacionais esteja consolidada, o que é denominado acumulação incompleta; e ( $v$ ) pode ocorrer o enfraquecimento (ou mesmo perda) de capacidades inovadoras já acumuladas ou reversão tecnológica.

A aplicação desse sistema de mensuração teve grande ímpeto a partir de 1999, no âmbito do Programa de Pesquisa em Aprendizagem Tecnológica e Inovação Industrial da EBAPE/FGV, tendo sido realizados mais de 25 estudos em empresas de várias indústrias ao redor do Brasil, que chegaram a resultados extremamente reveladores sobre capacidades 
tecnológicas e de inovação no país. Ademais, tem sido amplamente aceito pela comunidade científica internacional, cujo reconhecimento reflete-se na aplicação dessa mensuração em vários estudos publicados em prestigiadas revistas científicas internacionais e em iniciativas de desenvolvimento industrial.

Convém esclarecer que não se está sugerindo qualquer tipo de superioridade dessa abordagem para exame de capacidades tecnológicas empresariais em relação à abordagem à base de surveys de inovação, que adota uma perspectiva macro ou agregada que permite, , metaforicamente falando, obter uma visão da "floresta", enquanto a nossa abordagem, baseada em tipos e níveis de capacidade tecnológica nas empresas, fornece uma perspectiva de "árvores" específicas ou de um grupo ou espécies de uma floresta. São abordagens complementares e importantes para o desenho e implementação de estratégias empresariais e governamentais de inovação industrial, assim como para decisões de investimentos em inovação.

Por outro lado, uma perspectiva sobre o processo de acumulação de capacidades tecnológicas em empresas específicas de determinadas indústrias e setores, como será feito com a abordagem baseada em tipos e níveis de capacidade tecnológica em empresas e startups, possibilitará a identificação de nuanças e pormenores altamente importantes para obter uma visão com adequado nível de detalhe e profundidade. Possibilitará, também, captar a dinâmica de acumulação de capacidades para funções tecnológicas específicas de produção e inovação.

Uma abordagem dessa natureza, pouco explorada em larga escala no Brasil até recentemente, permitirá a captação de nuanças, especificidades empresariais, setoriais e regionais do processo de acumulação de capacidades tecnológicas, tornando-se de crucial importância como clarificadora, iluminadora e apoiadora do processo de desenho, redesenho, implementação e ajuste de estratégias de desenvolvimento de capacidades tecnológicas em empresas na indústria. Servirá, portanto, como uma perspectiva complementar à abordagem em nível agregado presente nos estudos já existentes. Por sua simplicidade, associada ao seu nível de detalhe e rigor analítico e de aplicação, também pode ser empregada pela própria empresa, por meio de iniciativas de seus gerentes, como um exercício de autoavaliação de sua capacidade tecnológica. 


\section{B: mecanismos de aprendizagem tecnológica (intra e interorganizacionais).}

Referem-se aos vários mecanismos pelos quais as empresas formam e acumulam suas capacidades inovadoras. Em outras palavras, a "aprendizagem" é analisada como dados para formação da capacidade de inovação das empresas. Portanto, se as empresas buscam aprofundar suas capacidades inovadoras rapidamente para cruzar as descontinuidades tecnológicas de forma efetiva e para inovar na fronteira, precisam envidar esforços na aprendizagem intensiva para adquirir e criar os recursos necessários. Neste projeto de pesquisa, será tomado como base a afirmação de que a aprendizagem no sentido de formação e aprofundamento das capacidades para inovar é consciente, deliberada, e não automática e passiva.

Serão coletadas evidências, ou seja, esforços de aprendizagem dentro de empresas e startups individuais, a serem examinados e medidos com relação aos mecanismos de aprendizagem e atividades de dois tipos: aqueles internos à empresa e aqueles em que a empresa adquire elementos de capacidade por meio de vínculos externos com outras organizações. Esses dois tipos de mecanismo de aprendizagem envolvem, por exemplo, aquisições de conhecimento via contratação de profissionais, vários tipos de treinamento para adquirir conhecimento para inovação, assim como mecanismos de aprendizagem para assimilar ou absorver os vários tipos de conhecimento obtidos externamente para a realização de atividades inovadoras.

C: "impactos" da acumulação de capacidades tecnológicas. Os "impactos" de capacidades inovadoras e de aprendizagem serão examinados conforme seu efeito sobre o desempenho das startups, empresas e da indústria. A forma como as empresas acumulam suas capacidades tecnológicas é algo que impacta sua performance competitiva. Especificamente, o alcance de performance distintiva está associado aos tipos e níveis de capacidade tecnológica que as firmas acumulam, os quais permitem a elas implementar atividades de produção e, principalmente, de inovação. Como a inovação agrega valor a produtos e serviços, possui impacto direto no crescimento da indústria e da economia.

Por meio da inovação, podem-se ampliar mercados, criar demandas novas, antecipar-se a demandas do mercado e, consequentemente, conquistar e assegurar mercados internos e internacionais. Desse modo, a acumulação de capacidades tecnológicas, especialmente as inovadoras, impacta o alcance, sustentação e ampliação da 
competitividade industrial. Portanto, quanto às startups, empresas e indústrias, constitui insumo fundamental para o crescimento industrial e econômico. Entre os indicadores de desempenho, serão examinados: (i) produtividade do trabalho e do capital; (ii) capacidade para exportar; e (iii) implementação de atividades derivadas da capacidade inovadora e da aprendizagem.

\section{D: influências indiretas, em nível da indústria e da economia, na acumulação de} capacidades tecnológicas de empresas. É óbvio o papel exercido pelas estruturas institucionais no processo de desenvolvimento tecnológico e industrial de uma nação. Muito embora o processo de inovação ocorra em startups e empresas, as universidades e institutos de pesquisa apoiam-nos de várias formas, como, por exemplo, fornecendo capital humano qualificado, complementando atividades de pesquisa demandadas pela indústria e gerando ciência, que pode ser utilizada pela indústria (embora não haja linearidade, ou seja, a produção de ciência nas universidades e institutos públicos de pesquisa não significa, necessariamente, a geração de inovação industrial e, em vários casos, esta não depende da ciência produzida em universidades).

Trata-se aqui das políticas em âmbito federal, estadual e local, desenvolvidas intencionalmente, isto é, regulamentos, leis, normas, regras do jogo, instruções de política e programas com objetivos implícitos e explícitos de influenciar o desenvolvimento da Ciência, Tecnologia e Inovação (CT\&l). As regularidades do comportamento incluídas nas orientações de política, normas, regras, leis e rotinas podem criar incentivos positivos ou negativos que estimulam ou inibem o progresso tecnológico nas empresas selecionadas e o progresso industrial nas empresas e indústrias selecionadas.

Especificamente, é útil classificar as políticas públicas em duas dimensões: quanto ao seu tipo - provisão de bens públicos ou intervenções no mercado - e quanto à sua transversalidade - vertical (limitada a algumas poucas indústrias) ou horizontal (de alcance industrial mais amplo). Prover educação de qualidade, investir em infraestrutura, garantir direitos de propriedade e reduzir a burocracia nos negócios são exemplos de políticas horizontais na provisão de bens públicos. Criar universidades de engenharia, por exemplo, implica a provisão de bens públicos, mas de natureza vertical, pois atende a determinadas indústrias (eletrônicos, por exemplo), mas não a outras. Por sua vez, existem políticas que 
distorcem os preços relativos de indústrias específicas (subsídios e proteção comercial para determinadas indústrias).

Finalmente, há intervenções de mercado que buscam atingir atividades específicas (subsídios para P\&D, para treinamento de mão de obra e para investimento em capital, por exemplo) e não determinadas indústrias.

\section{3 Áreas Tecnológicas em Biotecnologia para Saúde Humana}

Durante a etapa de construção do questionário que será aplicado aos participantes, observou-se que dois desafios permeiam a análise sobre inovação no setor de biotecnologia para saúde humana. Primeiro, devido à escassez de estudos relacionados à inovação no setor de biotecnologia para saúde humana no mundo, não existem referências sobre os graus de novidade para classificar as atividades tecnológicas dentro do ou relacionado ao modelo de maturidade de capacidade tecnológica apresentado na figura 3. Segundo, mesmo se tratando de um setor considerado de alta tecnologia, OECD (2009), é de suma importância ter uma distinção muito clara entre o que é capacidade tecnológica para utilização de processos biotecnológicos já existentes, mesmo estes sendo altamente sofisticados, como exemplo a tecnologia de edição de genes conhecida como CRISPR, destacada em Hupffer (2020), acrônimo em inglês, Clustered Regularly Interspaced Short Palindromic Repeats, ou "Conjunto de repetições palindrômicas curtas, agrupadas e regularmente interespaçadas", e o que é capacidade tecnológica para inovação, para desenvolver novos processos e produtos biotecnológicos.

Para superar esses desafios e conseguir aplicar o modelo apresentado na figura 3 para as atividades tecnológicas desenvolvidas pelas startups e empresas, optou-se com base em $\operatorname{OECD}(2005$, p. 8) por construir o formulário levando em consideração aspectos como:

Ferramentas Tecnológicas - Definida como a atividade, ou processo biotecnológico exercido pela empresa em termos de execução da sua atividade principal, estratificados com base na definição da OCDE (2009) e adaptado recentemente por Uziel (2018) em estudo relacionado à biotecnologia para saúde humana, optou-se por cinco grupos de ferramentas tecnológicas: manipulação de DNA/RNA, manipulação de Proteínas e outras 
moléculas, Cultura de células/tecido e Engenharia, Bioinformática e Nanobiotecnologia. Será detalhado na seção 4 .

Produto e uso final - Representa o produto ou processo biotecnológico final, ou seja, o entregável resultante da combinação entre a técnica de biotecnologia relacionada e sua aplicação. Neste aspecto, será possível identificar inicialmente certo grau de novidade da técnica em relação à atividade.

Técnica de Biotecnologia - Representa a técnica, ou atividade tecnológica que as startups e empresas realizam em suas rotinas operacionais, procedimentos ou práticas aplicadas à biotecnologia para saúde humana.

Aplicação - Entendida no estudo como o objetivo de utilização das técnicas de biotecnologia ou atividades tecnológicas, descritas anteriormente, sob um olhar individualizado. Dessa forma, a técnica como parte de rotina operacional pode ser utilizada com ou sem adaptações ou melhorias, ou até levando ao desenvolvimento de novos produtos e/ou processos biotecnológicos, o que será avaliado em cada etapa.

Grau de novidade - Por fim, será identificado o grau de novidade que o produto ou processo biotecnológico representa, em termos de novo para a empresa, para o país ou para o mundo, conforme níveis de 1 a 5 na Figura 3.

Portanto, a composição desses aspectos como escolha e identificação por parte dos respondentes servirá como importante insumo da pesquisa que permitirá a equipe alocar cada respondente, com base em suas atividades tecnológicas reveladas, no modelo apresentado na Figura 3. Além desse primeira análise para saber se as startups e empresas realizam tais atividades tecnológicas, outros três pontos serão analisados: primeiro, como essas startups e empresas realizam tais atividades, se sozinhas ou em parcerias com outras empresas, institutos de ciência e tecnologia (ICTs), laboratórios, entre outros parceiros; segundo, como essas startups e empresas fizeram ao longo dos anos, especificado em três períodos (2012-2014, 2015-2017 e 2018-2020), para desenvolver capacidades para realizar tais atividades tecnológicas, identificando quais mecanismos internos e externos utilizados; e terceiro, quais os esforços feitos pelos respondentes para absorver, criar e acumular conhecimentos que permitam a realização das atividades tecnológicas descritas anteriormente sobre biotecnologia para saúde humana, identificados na Figura 2 como "mecanismos intra e interorganizacionais de aprendizagem".. 


\section{Desenho e Método de Pesquisa}

Esta seção descreve o desenho e o método utilizados nesta pesquisa, dividindo-se em: (i) apresentação da estratégia da pesquisa; (ii) procedimentos e critérios para escolha da indústria e suas organizações; (iii) procedimentos e critérios para coleta de evidências.

\subsection{Estratégia da pesquisa}

Conforme entendimento das questões a serem investigadas e da base analítica da pesquisa, a implementação da metodologia envolveu um extenso exame intra e intersetorial e em nível de empresas e startups, além de instituições de apoio como institutos de ciência e tecnologia (ICTs), universidades e HUBs de inovação, com cobertura ao longo do período de 2012 a 2020. Essa cobertura permitirá captar nuanças e mudanças ao longo do tempo nas questões investigadas, ou seja, a dinâmica do processo de acumulação de capacidades tecnológicas e seu impacto na competitividade industrial.

A estratégia de pesquisa seguirá o modelo analítico de quatro etapas apresentado na Figura 2. Primeiramente, será identificado, ao longo do tempo, níveis e padrões de acumulação de capacidades tecnológicas de empresas e startups no setor de biotecnologia para saúde humana. Num segundo momento, será analisado o que influenciou os níveis e padrões de acumulação de capacidades tecnológicas por meio da incidência de diferentes mecanismos de aprendizagem implementados pelas empresas e startups. Por fim, será inferido os resultados gerados pela acumulação de capacidades tecnológicas por meio de impactos no desempenho competitivo das empresas (avanços em processos e produtos biotecnológicos e inserção internacional). Essas três etapas buscarão analisar não apenas diferenças e semelhanças entre as empresas e startups de biotecnologia para saúde humana pesquisadas, mas também áreas tecnológicas distintas dentro das próprias empresas e startups. Para esta pesquisa, serão utilizadas como parâmetros de medida as ferramentas tecnológicas de DNA/RNA, Proteínas e outras moléculas, Cultura de células/tecido e Engenharia, Bioinformática e Nanobiotecnologia.

A pesquisa será baseada em evidências empíricas primárias colhidas diretamente do setor de biotecnologia para saúde humana (em nível de setores industriais e empresas), por meio da aplicação de questionários e entrevistas, combinada com trabalhos de campo, que 
em virtude das medidas de distanciamento ocasionadas pela pandemia da COVID-19, foram realizadas através de vídeo chamada tanto na etapa de workshop, quanto na etapa de entrevistas. Essas evidências serão complementadas por evidências secundárias de fontes oficiais industriais e governamentais e por evidências empíricas obtidas, a priori, de uma base de dados composta por trabalhos desenvolvidos no âmbito do Programa de Pesquisa em Aprendizagem Tecnológica e Inovação Industrial no Brasil, da EBAPE/FGV.

No intuito de aumentar o potencial de impacto a ser gerado por esta pesquisa na sociedade e sua aplicabilidade, uma de suas características marcantes foi a forte conexão e interação com tomadores de decisão (empresas, startups, instituições e governo), que foram integrados ao processo da pesquisa desde a etapa inicial. Para isso, foram realizados até o momento, doze sessões de workshop com gestores empresariais, tanto de empresas e startups quanto com gestores e dirigentes de associações e suporte à inovação, habitats de inovação e pesquisadores de universidades e institutos de pesquisa. Todos esses atores discutiram as principais questões prementes e as necessidades, em nível empresarial, de indústria e governamental, concernentes à inovação e à competitividade industrial. Assim, o projeto baseia-se numa forte interação com empresas e outras instituições vinculadas aos respectivos setores, sendo esse outro grande diferencial em relação a pesquisas mais convencionais sobre inovação.

\subsection{Escolha das organizações}

Devido aos constantes avanços tecnológicos vivenciados no país e o potencial de impacto que as startups possuem na economia global e nos negócios, optou-se por selecionar startups pertencentes ao setor de biotecnologia para saúde humana, assim como empresas estabelecidas dos setores farmacêuticos, farmoquímicos e biotecnológicos. Todas as startups e empresas selecionadas no estudo são de origem ou possuem atuação direta no Brasil.

O Gráfico 1 apresenta a quantidades de empresas e startups selecionados ainda na etapa de workshop e entrevistas iniciais identificados como potenciais participantes a serem entrevistados no estudo, para melhor identificá-las, foram estratificadas em 16 especialidades distintas nas quais estas companhias atuam, conforme gráfico abaixo, podendo uma mesma empresa estar inserida em mais de um nicho. 
Gráfico 1: Empresas consolidadas e Startups potenciais selecionadas por especialidade.

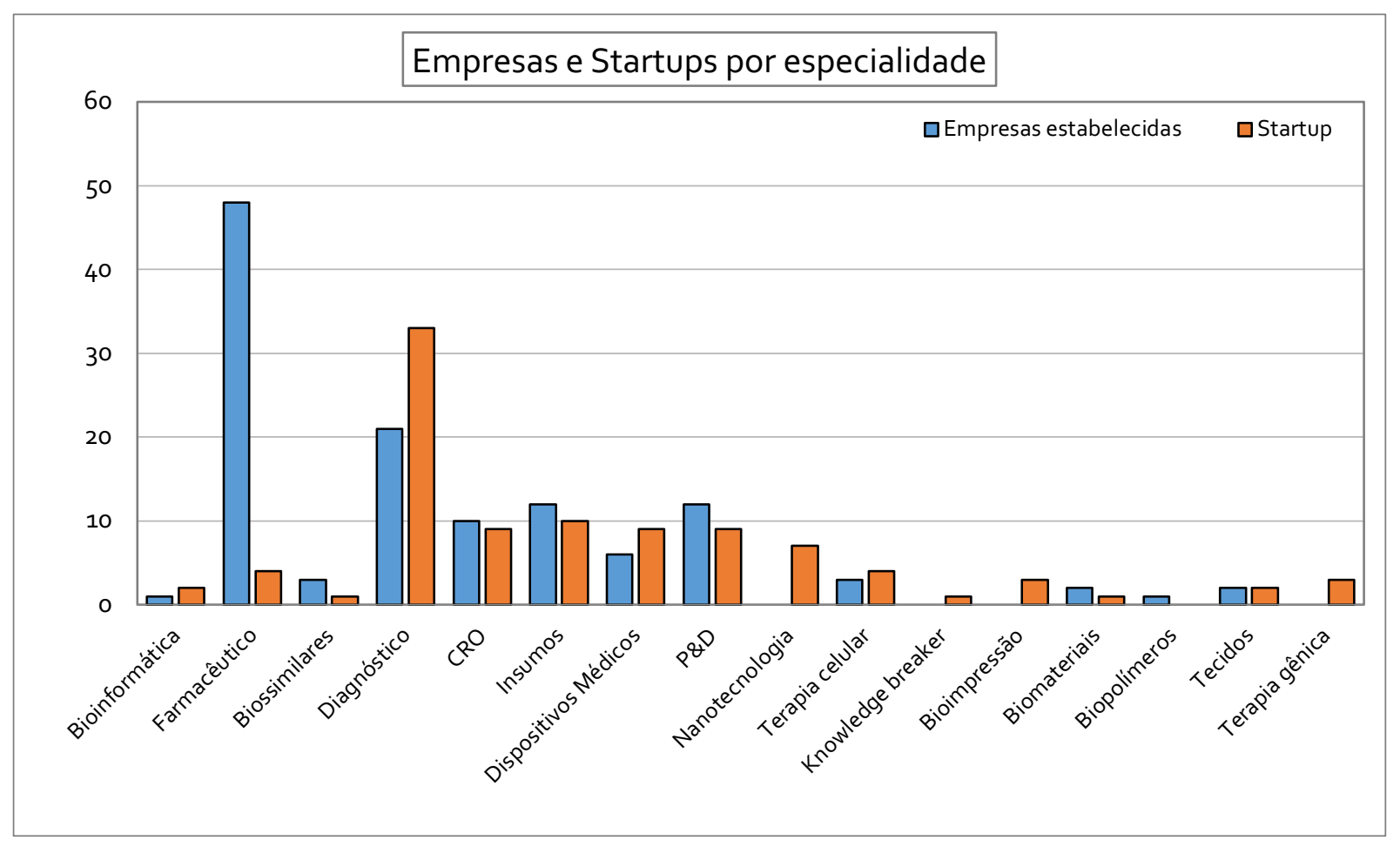

Fonte: Os autores (2021).

Portanto, até o momento, o estudo abrange uma amostra potencial com 86 startups e 106 empresas, relacionados no Gráfico 1, e outras 33 instituições (ICTs e CRO), porém estes números podem sofrer alterações até a finalização do estudo, visto que algumas entrevistadas podem ser desconsideradas ao longo das interações e respostas. Essa desconsideração poderá acontecer porque, para o presente estudo, serão consideradas apenas startups e empresas que de fato apliquem ciência e tecnologia em organismos vivos visando a produção de conhecimentos, produtos e serviços para saúde humana, (OCDE, 2009). Nesse contexto, novas startups, empresas e instituições também poderão ser inseridas nas próximas interações.) pois embora diversas organizações apresentem a biotecnologia como possível ramo de atuação, principalmente devido ao impacto e relevância que o termo vem recebendo ao longo dos últimos anos, para o presente estudo, serão consideradas apenas startups e empresas que de fato apliquem ciência e tecnologia em organismos vivos visando a produção de conhecimentos, produtos e serviços para saúde humana, (OCDE, 2009), assim como outras startups, empresas e instituições podem ser inseridas ao longo das próximas interações. Ressalta-se que como "empresas 
estabelecidas", foram incluídas empresas de todos os portes pertencentes aos setores farmacêuticos, farmoquímicos e biotecnológicos, que mesmo as pertencentes aos dois primeiros setores não sendo atuantes exclusivamente ou parcialmente no setor de biotecnologia, se faz necessário entender com certo grau de detalhes se e como essas empresas estabelecidas tem feito algum esforço para acumular capacidades tecnológicas relacionados à biotecnologia para saúde humana, visto que esse movimento, dos setores farmacêuticos e farmoquímicos para atuarem também no biotecnológico, foi mencionado durante a etapa de workshop e entrevistas, está sendo feito por farmacêuticas nacionais de grande porte e multinacionais que ao longo das últimas décadas tem empregado esforços significativos em Pesquisa e Desenvolvimento (P\&D), Merges and Acquisitions, entre outros mecanismos, para acumular tais capacidades tecnológicas para melhorar e desenvolver novas tecnologias relacionadas, em um primeiro momento, para avanços em fármacos e posteriormente feito avanços em biossimilares, movimentos para acumular capacidade tecnológica inovadora que as permitam entrar na rota tecnológica que a biotecnologia proporciona ao setor de saúde humana no Brasil, movimento semelhante ao ocorrido no país no início do século 21 com o caso dos genéricos, Brasil (1999), essas empresas buscam aproveitar a janela de oportunidade que a biotecnologia proporciona para o setor de saúde no país e no mundo.

\subsection{Procedimentos e critérios para coleta de evidências}

O avanço da biotecnologia percebido ao longo das últimas décadas, assim como a pandemia de COVID-19, que dilatou a dependência do país para o suprimento de insumos básicos, como os IFAs, e o desenvolvimento de novas vacinas para o combate da pandemia, foram pontos importantes para a escolha da biotecnologia para saúde humana no Brasil.

A inexistência prévia de uma base de dados consistente sobre os avanços do setor de biotecnologia para saúde humana no Brasil dificultou o processo de coleta de dados. Devido a essa lacuna de informação, foi intensificada a etapa de workshop, obrigando a equipe realizar mais sessões com o objetivo de levantar o maior número de evidências sobre as questões prementes do setor. Complementar as sessões de workshop, serão feitas entrevistas e aplicação de questionários individuais. 


\subsubsection{Workshop}

A primeira iniciativa na busca por informações sobre as questões prementes do setor e formulação das perguntas presentes nos questionários foi a realização de doze sessões de workshop, que contou com a presença de 67 representantes do setor, como empresas e startups produtoras, instituições de pesquisa e representantes de instituições de apoio à inovação. Realizado no período entre julho e novembro de 2021, através de plataforma de vídeo chamada, os workshops ocorreram, inicialmente na forma de debates entre 3 a 5 participantes divididos em grupos e posteriormente discutidos em plenária com a presença de todos os participantes. Entretanto, visto a riqueza de detalhes expostas nos grupos, optou-se por seguir a partir da terceira sessão de workshop somente com os debates em plenárias, nesses workshops foram apresentadas questões construídas com intuito de estimular a interação entre os participantes e levantar questões prementes do setor de biotecnologia para saúde humana no Brasil, de modo a extrair com maior grau de detalhe as experiências dos participantes e responder pontos importantes como:

Todos os workshops foram gravados, tendo as suas discussões transcritas pelos pesquisadores. As transcrições foram utilizadas principalmente para auxiliar na construção do questionário que será aplicado na etapa de coleta de dados e também para compor o roteiro de entrevistas que será realizado na etapa posterior ao questionário, para fundamentar qualitativamente os resultados encontrados pela análise quantitativa.

Tabela 1: Relação de participantes da etapa de workshop e entrevistas da pesquisa.

\begin{tabular}{|l|c|}
\hline \multicolumn{1}{|c|}{ Instituição } & Quantidades \\
\hline Startups & 24 \\
\hline Empresas estabelecidas & 15 \\
\hline Fundo de amparo a pesquisa & 1 \\
\hline Aceleradora de startups e empresas de base tecnológica & 1 \\
\hline Entidade de classe sobre Biotecnologia & 1 \\
\hline Entidade de classe do setor industrial nacional & 1 \\
\hline Parques Tecnológicos & 3 \\
\hline Núcleo de Inovação Tecnológica de Universidade Pública & 1 \\
\hline Institutos de Pesquisa Público & 2 \\
\hline
\end{tabular}




\begin{tabular}{|l|c|}
\hline Institutos de Pesquisa Privado & 2 \\
\hline Universidades Pública & 3 \\
\hline Universidade Privada & 1 \\
\hline HUB de inovação & 2 \\
\hline Escola relacionada a saúde pública & 1 \\
\hline
\end{tabular}

Fonte: Os autores (2021).

\subsubsection{Entrevistas}

Foram realizadas três entrevistas com representantes de instituições que servem de apoio à inovação em startups e empresas de biotecnologia no país, as quais foram semiestruturadas com caráter aberto para que o entrevistado tivesse liberdade de expor suas experiência e contribuições sobre os temas que foram destacados na etapa de workshop. Todas as entrevistas foram gravadas e transcritas para serem inseridas com caráter qualitativo no trabalho.

\subsubsection{Questionários}

A elaboração dos questionários está sendo feita com o intuito de levantar evidências das três etapas do modelo analítico da pesquisa representado na Figura 2, quais sejam: (i) acumulação de capacidades tecnológicas; (ii) impactos da acumulação de capacidades tecnológicas (desempenho competitivo); (iii) mecanismos intra e interorganizacionais de aprendizagem tecnológica, (iv) assim como a compreensão de se as influências indiretas estão sendo positivas, negativas ou neutras para a inovação por parte das startups e empresas. Esses questionários serão enviados a todas potenciais startups e empresas selecionadas para três triênios distintos de tempo: 2012-2014, 2015-2017 e 2018-2020, divisão importante para averiguar a trajetória da acumulação de capacidades tecnológicas e os avanços tecnológicos realizados pelas empresas e startups ao longo do tempo.

\section{Definição da Biotecnologia}

Conforme destacado em Uziel (2018), segundo a Organização para Cooperação e Desenvolvimento Econômico (OCDE, 2009), o termo biotecnologia é definido como "a aplicação da ciência e tecnologia aos organismos vivos, bem como partes, produtos e modelos dos mesmos, para alterar materiais vivos ou não vivos visando a produção de 
conhecimentos, produtos e serviços". Esta definição está fortemente relacionada ao que se entende por Biotecnologia Moderna, que teve como marco tecnológico a clonagem e recombinação do DNA por Cohen e Boyer em 1973, e que se contrapõe à Biotecnologia Clássica. A utiliza seres vivos encontrados na natureza para desempenhar determinada função produtiva, que podem ser melhorados por técnicas como isolamento, seleção e cruzamento genético entre espécies sexualmente compatíveis.

Ainda segundo a autora, devido a diversidade de aplicação da biotecnologia em diferentes ramos da atividade econômica, foi definido em 2004, na reunião da Comissão Europeia de Biociências e Tecnologia, da Universidade de York (Reino Unido), um sistema de classificação do uso da biotecnologia reunido de acordo com suas características comuns ou sua utilidade final. Decidiu-se classificar a biotecnologia através de um sistema de cores para cada ramo de aplicação; vermelho (Saúde), branco (Industrial), verde (Agricultura e afins) e azul (Marinha). Vale ressaltar que esse sistema de cores não é uma classificação oficial, porém é largamente difundido na identificação dos setores de atuação da biotecnologia.

\subsection{Características da Biotecnologia Vermelha}

O sistema que nos interessa nesta pesquisa é a de cor vermelha, a Biotecnologia Vermelha, a qual faz referência a cor do sangue, o vermelho, para identificar sua atuação da biotecnologia aplicada especificamente à saúde humana.

Para a definição das áreas tecnológicas selecionadas para o presente estudo, entre outros estudos, considerou o trabalho aplicado de Uziel (2018) para a biotecnologia vermelha e também as referências de estudos estatísticos de biotecnologia realizados em OECD (2009) e OECD (2005), portanto, a estrutura das áreas tecnologias foi definida da seguinte forma:

Tabela 2: Técnicas celulares e moleculares aplicadas à biotecnologia. Adaptado de OCDE, 2009 e Uziel, 2018.

DNA/RNA: genômica, farmacogenômica, sondas genéticas, engenharia genética, sequenciamento/síntese e amplificação de DNA ou RNA, perfil de expressão gênica, tecnologia antisenso 


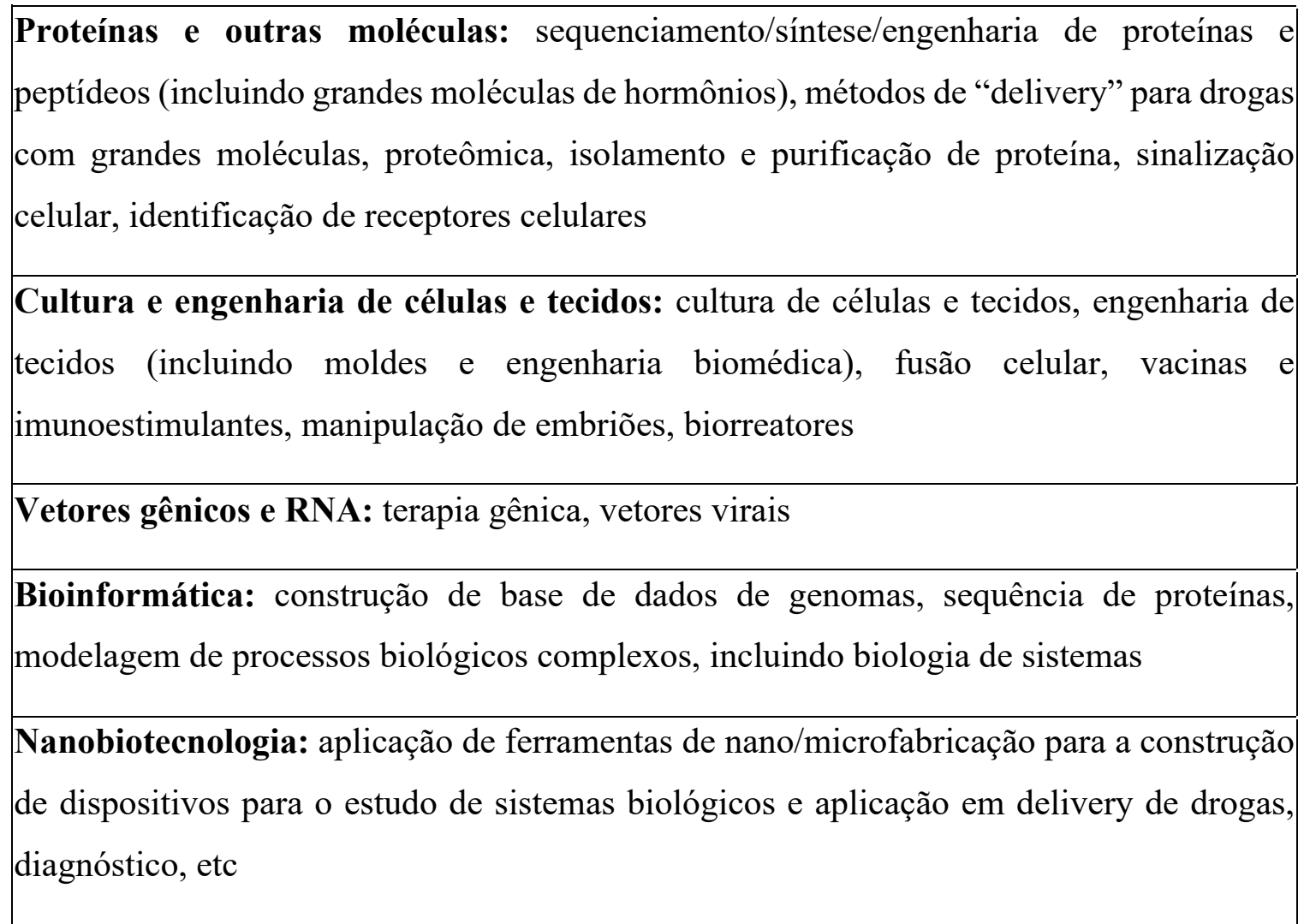

Fonte: Adaptado de Uziel (2018).

\section{Resultados Parciais da Pesquisa}

As diferenças entre as startups e empresas da indústria relacionada a biotecnologia para saúde humana no Brasil no que diz respeito à sua acumulação de capacidades tecnológicas entre 20012 e 2020 são o foco de análise desta seção, que obedece ao desenho de pesquisa apresentado na seção 2. Dessa maneira, busca-se delimitar níveis e padrões de acumulação de capacidades tecnológicas, a influência dos mecanismos de aprendizagem que geram esses padrões e a relação entre a capacidade tecnológica e o desempenho competitivo das startups e empresas da indústria brasileira relacionada à biotecnologia para saúde humana no período mais recente. Essas análises visam, ainda que parcialmente devido ao estágio inicial da pesquisa, na medida do possível, identificar e quantificar essas relações por padrões de acumulação de capacidades tecnológicas e por área tecnológica. Ressalta-se que fazem parte da indústria relacionada à biotecnologia para saúde humana as startups, empresas estabelecidas e os institutos de pesquisa.

A seção encontra-se organizada em seis subseções que apresentam resultados obtidos na etapa de workshops e entrevistas: a subseção 5.1 apresenta um resumo dos 
resultados qualitativos sobre a importância da biotecnologia para fortalecer o quadro de saúde pública, o déficit comercial e também sobre o desenvolvimento tecnológico do setor para saúde humana no Brasil; a subseção 5.2 mostra um breve resumo de algumas atividades realizadas pelas startups e empresas no setor; a subseção 5.3 apresenta as principais relações de colaboração que startups e empresas realizam com outras instituições, além de destacar o que poderia melhorar nessas relações; as subseções seguintes apresentam relatos sobre as experiências dos participantes de workshops e entrevistas, em termos do que há de bom e o que necessita ser melhorado no setor. Os relatos sobre dificuldades encontradas foram relacionados aos seguintes pontos: na subseção 5.4, à propriedade intelectual; na subseção $5 \cdot 5$, ao ambiente regulatório para saúde humana no país; e, por fim, a subseção 5.6 apresenta a experiência com Funding.

\subsection{Importância da biotecnologia}

Em relação aos destaques apresentados na seção introdutória sobre crescimento e envelhecimento da população, bem como o aumento da expectativa de vida, conforme destacado em Perelmuter (2019), estima-se que em 2050, cerca de 16\% da população mundial terá 65 anos ou mais, contra $8 \%$ em 2010, e que esses aumentos na concentração da população mais velha pode chegar em até $250 \%$ nos países em desenvolvimento, caso do Brasil. Ainda segundo o autor, os números apresentados no gráfico do Brasil mostram uma significativa mudança na pirâmide populacional, saindo de uma base majoritariamente predominante de jovens e adultos até 29 anos vivenciado em 1970, para uma distribuição próxima de $3 \%$ entre as faixas dos primeiros anos de vida até os 69 anos, englobando uma leve concentração superior entre os 40 e 60 anos, e um avanço significativo das faixas seguintes superiores e até o surgimentos dos centenários.

Essas mudanças na população podem trazer implicações econômicas relevantes para governos e para a sociedade, não somente pelo número de pessoas impactadas, mas também pelos custos crescentes diretos dos sistemas de saúde, assim como custos indiretos relacionados a seguridade social, como pagamentos de aposentadorias e auxílio-doença. Conforme apresentado em IPEA (2020), a Medicina de Precisão se baseia em características genéticas dos indivíduos para redefinir tratamentos e, potencialmente, impactar os custos, portanto, pode ser um importante aliado à Biotecnologia, tanto no desenvolvimento de 
tecnologias relacionadas a diagnóstico como no tratamento de doenças crônicodegenerativas, intimamente ligadas à melhora da qualidade de vida e envelhecimento populacional, que representam altos custos para a saúde, tanto pública quanto privada. Portanto, fortalecer o sistema de saúde pública, o SUS, para que seja altamente eficiente no tratamento das doenças que mais afetam as alterações demográficas da população no país e reduzir os gastos públicos pode ser um importante passo para posterior avanço no desenvolvimento do setor biotecnológico para saúde humana no país.

\subsubsection{Fortalecer o quadro da saúde pública no Brasil}

Entre os principais benefícios esperados pela biotecnologia para a saúde pública estão os avanços em tecnologias relacionadas ao tratamento de doenças crônicas não transmissíveis (DCNT), descritas em inglês, Noncommunicable diseases (NCDs), como doenças cardíacas, mal de Alzheimer e outras demências, obesidade, neoplasias malignas, diabetes mellitus e doenças respiratórias crônicas, que são as principais causas de mortes no mundo, especificamente no Brasil, e responderam por 74\% das mortes no país, ou 975 400 mortes, segundo o relatório da OMS (2020). Apesar de os tratamentos para essas doenças estarem muito concentrados em grandes indústrias farmacêuticas e farmoquímicas, mas também estão em crescente exploração pelas startups, que costumam ser formadas, em grande parte, por estudantes de cursos relacionados à saúde, química e biologia, o que enfatiza a crucialidade da formação de bons profissionais para preparar as mentes pensantes que irão preencher funções nessas corporações. Alguns relatos por parte das startups, empresas e instituições são:

Tabela 3: Depoimentos coletados dos participantes dos workshop e entrevistas.

\begin{tabular}{|c|c|c|}
\hline Empresas & Startups & \multicolumn{1}{|c|}{ Instituições } \\
\hline Falta cultura empreendedora & O país vive uma crise terrível na & Universidades precisam ser mais \\
dentro das universidades. & área de tecnologia devido à falta & proativas na formação de \\
& de mão de obra & profissionais com diferentes \\
\hline
\end{tabular}




\begin{tabular}{|c|c|c|}
\hline $\begin{array}{l}\text { Há dificuldade no Brasil tanto na } \\
\text { formação de alunos como na } \\
\text { conexão da pesquisa acadêmica } \\
\text { com demandas da sociedade. }\end{array}$ & $\begin{array}{l}\text { Falta nas universidades cursos de } \\
\text { empreendedorismo e finanças } \\
\text { aos pesquisadores para } \\
\text { desenvolver e transformar } \\
\text { pesquisa em negócio. }\end{array}$ & $\begin{array}{l}\text { perfis, tanto acadêmico quanto } \\
\text { empreendedor. Uma forma de } \\
\text { contornar este problema seria } \\
\text { através da criação de cursos } \\
\text { relacionados }\end{array}$ \\
\hline $\begin{array}{l}\text { Brasil tem formação } \\
\text { acadêmica qualificada, mas falha } \\
\text { em unir a excelência acadêmica } \\
\text { com empreendedorismo. }\end{array}$ & $\begin{array}{l}\text { Falta homogeneidade entre } P \& D \\
\text { e Empreendedorismo na } \\
\text { formação dos profissionais. }\end{array}$ & $\begin{array}{l}\text { empreendedores com ênfase em } \\
\text { inovação na área de saúde. }\end{array}$ \\
\hline
\end{tabular}

Fonte: Elaborado pelos autores (2021).

\subsubsection{Reduzir o déficit comercial vivido pelo país nos últimos anos}

Desenvolver uma indústria nacional de insumos pode ser uma alternativa para reduzir a necessidade de importação de insumos e produtos biotecnológicos, farmacêuticos e farmoquímicos por parte da indústria local, além de permitir o amadurecimento e crescimento de empresas locais, essa é uma alternativa que pode contribuir para amenizar o déficit comercial negativo presenciado pelo país nos últimos anos no setor de saúde pública. Sobre esse aspecto de insumos, os comentários feitos durante os encontros foram:

Altos preços na importação de insumos prejudicam a competitividade de pequenos laboratórios no Brasil, principalmente para competir no cenário internacional;

$\checkmark$ Serviços essenciais, como o armazenamento em nuvem, contratado no exterior tem custo menor do que se fosse contratado dentro do Brasil;

$\checkmark$ Falta uma política para fortalecer a produção local de insumos;

$\checkmark$ Falta política pública para taxas de importação;

$\checkmark$ Dificuldade na continuidade do oferecimento de produtos biotecnológicos e na qualidade dos mesmos;

Tais experiências corroboram com os dados apresentados no início do estudo, que relacionam a ausência de uma indústria nacional de insumos ao aumento das importações, ocasionando altos custos para a indústria local. Além desses destaques, os participantes 
pontuaram sobre a necessidade de políticas consistentes que fortaleçam a competitividade dos laboratórios nacionais de pequeno porte, assim como das startups, que necessitam de acesso a insumos e infraestrutura, principalmente nas etapas de desenvolvimento préclínico e clínico, feitos na fase de validação, que antecede a aprovação pelo regulatório e consequente comercialização.

\subsubsection{Para o desenvolvimento tecnológico do setor de saúde no país}

Avanços em medicina regenerativa, como engenharia de tecidos, biomateriais e terapias celulares, ou em genômica, como engenharia genética, sequenciamento de DNA ou RNA, associados a tecnologias digitais como inteligência artificial e big data para uso em bioinformática, podem ocasionar o descobrimento de novas drogas, construção de base de dados de genomas, modelagem de processos biológicos complexos, dentre outros. Essas são importantes áreas que se exploradas com sucesso pelas empresas e startups nacionais irão contribuir para o fortalecimento do setor de saúde humana, e consecutivamente, o sucesso de tais organizações poderão trazer inúmeros benefícios para o país, tanto em forma de tecnologias nacionais para atender ao SUS, como investimentos internacionais, melhora no ambiente de negócios, entre outros.

Quanto ao termo desenvolvimento tecnológico no país, vale destacar o comentário feito por um representante de uma das pouquíssimas empresas de grande porte nacional de biotecnologia.

Falta infraestrutura no Brasil para o desenvolvimento de biotecnológicos. Obviamente você vai contratar serviços no exterior, nada errado com isso, só que no Brasil se você é uma empresa você paga um imposto de mais de 40\%, então todas essas etapas de desenvolvimento tem um custo adicional brutal. Isso precisa de ajustes para fortalecer a indústria local.

\subsection{Um breve cenário das atividades realizadas no setor}

Diante da amostra potencial que está sendo trabalhada dentro do estudo, listamos a seguir algumas atividades que foram apresentadas pelos participantes durante os workshops, mesmo que ainda não analisados em detalhes os dados que serão coletados pelos surveys e 
qualificados posteriormente com entrevistas. Vale destacar algumas atividades já identificadas por parte de empresas e startups:

Desenvolvimento de plataforma para descobrimento de novas drogas, envolvendo o uso de bioinformática com base em P\&D em parcerias com institutos de pesquisa;

> Processo biotecnológico complexo que envolve engenharia genética para o desenvolvimento de anticorpos monoclonais;

$>$ Desenvolvimento de novos fármacos para tratamento do câncer através de síntese química para a produção de peptídeos;

$>$ Desenvolvimento de medicamento novo para o mundo para tratamento de um tipo de câncer de mama;

$>$ Desenvolvimento de diversos kits de diagnósticos para diversas aplicações como COVID-19;

$>$ Biofabricação de proteínas humanas;

> Desenvolvimento de antígenos para diversos tipos de vacinas;

$>$ Produção de biologia sintética aplicada ao fornecimento de kits de síntese de proteínas recombinante;

Uso de bioimpressão ${ }_{3} D$ para a criação de órgãos bioartificiais e tecidos em laboratório.

Ainda não foi comprovado se essas capacidades tecnológicas, por parte das startups, são capacidades tecnológicas reveladas e já atuam no desenvolvimento de inovações próximas ou na fronteira tecnológica (níveis 4 e 5 da Figura 3), prestes a se tornarem verdadeiros unicórnios (termo designado a startups avaliadas em mais de 1 bilhão de dólares antes de abrir capital em bolsa de valores (CB Insights, 2021), para o setor de biotecnologia e saúde), ou se são potenciais capacidades tecnológicas, consideradas "capacidades latentes" por ainda estarem na etapa de invenção, conforme descrito na seção 2, e por parte das empresas estabelecidas, capacidades tecnológicas para desenvolver inovações nos quatro níveis, desde pequenas adaptações até inovações mais radicais, passando por avanços em indústrias farmacêuticas e farmoquímicas direcionadas à biotecnologia. Além de validar se tais esforços no acúmulo de capacidades tecnológicas feitas por startups e empresas, o 
estudo buscará identificar o que tem prejudicado, interna e externamente, essas capacidades latentes de resultarem em inovações no mercado nacional e internacional em termos de produtos e processos biotecnológicos. Outro ponto a ser analisado dentro do estudo será quanto ao potencial que a infraestrutura existente em alguns institutos de pesquisa no país pode exercer no desenvolvimento de inovações para o setor.

Um comentário feito durante o workshop que merece destaque é relacionado a quantidade de empresas de biotecnologia no país:

Quando em relação a implantação de PDPs, é um convênio tripartite, envolve a instituição multinacional que detém a tecnologia, uma privada nacional e uma pública, tem uma escassez de empresas privadas nacionais de biotecnologia, existe um grupo muito grande de farmoquímicas, muito baseado em genéricos, mas temos dificuldade até mesmo de identificar quem são os parceiros privados nacionais que teriam capacidade para absorver uma tecnologia de produção de biológicos, hoje a gente conta no dedo, na verdade uma mão é suficiente. Não excede todos os dedos de uma mão dessas empresas, e é uma dificuldade imensa.

Portanto, comentários dessa natureza mostram como falta no país empresas capacitadas a atuarem com biotecnologia, até mesmo para absorver os benefícios esperados para as políticas públicas, como foi o caso das PDPs.

\subsection{Colaboração com outras instituições}

O objetivo desta subseção é apresentar, ainda que parcialmente, um breve panorama sobre o que está sendo positivo nas relações de colaboração entre empresas e startups com institutos de pesquisa, e o que necessita ser melhorado. Para isso, apresentamos abaixo alguns destaques coletados durante a etapa de workshops e entrevistas realizadas até o momento.

Os pontos positivos destas interações entre startups e empresas são destacados abaixo:

- Ligação das startups com universidades e institutos de pesquisa 
Praticamente todas as startups participantes dos workshops nasceram, desenvolveram ou ainda mantem relações de Co-desenvolvimento com universidades e institutos de pesquisas que seus fundadores realizaram seus estudos de graduação, mestrado, doutorado, pós-doutorados ou projetos de pesquisa;

\section{- Empresas estabelecidas com institutos de pesquisa, startups e outros atores do ecossistema}

Diversas empresas estabelecidas revelam ter constantes interações para compartilhamento de conhecimento, execução de projetos em parcerias e aquisição de conhecimento com institutos de pesquisa, assim como programas de integração de startups, para Co-desenvolvimento ou mesmo aquisição de startups, os Merge \& Acquisitions. Isso indica que estão sendo feitos avanços em inovação aberta (open Innovation) dentro do setor farmacêutico, farmoquímico e biotecnológico. Alguns comentários relatados em workshops foram:

$\checkmark$ Grandes empresas farmacêuticas estão começando a usar o Open Innovation (Inovação Aberta), onde a empresa quer que o pesquisador da universidade resolva o problema dela e o resultado da solução é da empresa;

Alguns pontos, destacados em forma de comentários dos participantes, que necessitam de melhorias sobre as interações entre os diversos atores do ecossistema são:

$\checkmark$ Falta colaboração entre a universidade e as empresas, destacando a necessidade de criação de cursos acadêmicos conjuntos, com uma interface entre empresa e universidade;

$\checkmark$ Falta suporte na gestão de assuntos relacionados a possíveis parcerias, além de grande dificuldade de estabelecer diálogos com as agências de inovação, que não ajudam na implementação de uma startup;

$\checkmark$ Não existe um "Fluxo de desenvolvimento tecnológico entre Universidade/startup/empresa". O ecossistema de inovação do país é muito fragmentado;

$\checkmark$ Necessidades de políticas públicas consistentes que fomentem a interação entre as instituições públicas e as grandes empresas, as quais detém maior capacidade de entrega e desenvolvimento de biotecnologias. 
$\checkmark \quad$ NITs de diversos estados não conversam entre si, de maneira que cada um possui uma infraestrutura jurídica própria, tornando uns mais aptos do que outros. NITs não entendem as demandas da indústria;

Outro ponto relevante abordado por um integrante de uma instituição diretamente ligada a saúde pública no país, foi sobre a política nacional que visa ampliar o acesso a medicamentos de alto custo no país dentro do SUS e fomentar o desenvolvimento produtivo interno, Brasil (2021), as Parcerias para o Desenvolvimento Produtivo (PDP), destacou:

A política de PDP no Brasil não está sendo cumprida por parte do Ministério da Saúde (MS), pois este acaba comprando um produto por licitação, que prejudica a política criada para construir um complexo "Bioindustrial" no Brasil, mas que não está cumprindo seu objetivo. Segundo o especialista, transferir uma tecnologia é caro, e ela não é só cara pelo valor financeiro, a empresa tem que se desprender de um ativo de Propriedade Intelectual, tem que passar uma receita de como produzir um anticorpo monoclonal ou outro produto, uma receita que as vezes é o core da empresa, então de fato o produto que contém embutido nesse "pacote" uma transferência de tecnologia tem que ser mais cara e isso de fato não é valorizado pelo comprador;

Ainda na temática PDPs, outro especialista de uma empresa de grande porte destacou:

a história das PDPs é uma das coisas mais tristes que eu vi no Brasil, uma ideia muito boa que eu acho que foi de 2012, mais ou menos, todo mundo sabe o que é, o governo iria comprar anticorpos biossimilares e outros biológicos de empresa brasileira, sim, se a empresa transfere a tecnologia e produz no Brasil e isso é um uso muito bom do poder de compra do governo para estimular a incorporação de biotecnologia no Brasil, porque até agora tem muito pouco, é muito caro, a ideia é muito boa, só que praticamente por causa das patentes levou 8 anos mais ou menos para começar a fazer as compras, e neste intervalo o governo, principalmente este governo agora deixou o preço desses medicamentos ir tão baixo, por licitação, etc quando não era necessário as empresas com os originadores fazendo dumping no Brasil, e a lei que 
fala depois que o governo tem que comprar pelo preço de última compra que atingiu uma grande farmacêutica nacional a continuar atuando nas PDPs, eles investiram centenas de milhões de reais em plantas de produção de anticorpos e teve que desistir, e isso foi praticamente a decisão de uma pessoa no ministério da saúde que não entendeu a política muito interessante, posso falar isso, a gente pode não ser a melhor coisa do mundo, mas foi uma ideia muito boa, e agora não sei o que vai acontecer, às vezes nem vai acontecer mais, e então não tem a segurança jurídica no Brasil, não tem continuidade. Biotecnologia tem um longo prazo e se nós não temos temas objetivos de longo prazo para este país e realmente ser um país tecnológico, científico, inovador, nunca vai ser, então acho, de novo, o que vocês estão fazendo está ótimo e o que estou ouvindo é mais ou menos isso de todo mundo, tem tanta pessoa aqui nessa call, com tanta vontade, fazer algo no Brasil, fazer algo interessante, inovar, se sacrificar e o governo só tem que deixar e não deixa, obrigado!

Comentários como esse demonstram a descontinuidade de políticas públicas, algo que impacta diretamente no desenvolvimento de capacidade tecnológica, pois é algo de longo prazo que envolve décadas, se não houver continuidade, nunca será possível evoluir esses pontos no país.

Para um especialista responsável por uma das poucas empresas de grande porte atuante em biotecnologia nacional, o comentário sobre transferência de tecnologia foi:

Grandes empresas já consolidadas vêm com ceticismo o investimento em startups dado o grande prazo o qual as startups precisam para se consolidar no mercado, com lacunas em áreas como negociação, fornecimento etc.

\subsection{Sobre a Propriedade Intelectual}

Outro tema apontado pelos participantes durante as discussões foi sobre Propriedade Intelectual. Na visão da grande maioria dos participantes, existem muitos pontos de melhorias que precisam de mais atenção dos órgãos responsáveis e principalmente por parte 
das universidades e NITs. Entretanto, vale destacar, antes das melhorias citadas, um ponto positivo elucidado por um integrante de startup:

Existem nas universidades brasileiras publicações de alto impacto, existe no país abundância de conhecimento, e a propriedade intelectual, passível de patentes, de proteção industrial onde você possa ter uma posição de competir a nível mundial como uma tecnologia que possa ser ou virar um produto, possa ser investido.

Os pontos de melhorias para o tema Propriedade Intelectual são:

$\checkmark$ Dificuldade em registrar uma patente internacional, em função da falta de apoio e de um núcleo, dentro da universidade, específico para auxiliar os pesquisadores neste ambiente regulatório;

$\checkmark$ Afirma que um dos motivos de motivação de investimento privado, é o respeito à Propriedade Intelectual (PI), e se isso não for garantido, pode-se esquecer qualquer tipo de investimento privado no Brasil. Relata que não faz o menor sentido o investidor colocar o recurso se não vai ter garantido exploração comercial dentro das leis, dentro da legislação;

$\checkmark$ Falta de valorização da propriedade intelectual nas academias brasileiras. Além disso, há publicações de alto impacto, mas pouco é gerado como produto comercial no Brasil.

$\checkmark$ Afirma que os períodos de análise de patente e registro são extremamente longos;

$\checkmark$ O Brasil deve fortalecer a Propriedade Intelectual (PI) para atrair o setor privado e ter o benefício de retorno dos investimentos que se faz na parte de desenvolvimento;

$\checkmark$ Existe um novo marco regulatório de ciência e tecnologia que saiv em 2016 e que modifica a lei de inovação, facilitando a interação entre universidade, empresa e instituições públicas e deve ser melhor utilizado;

$\checkmark$ Faltam profissionais com conhecimento em Propriedade Intelectual.

\subsection{Influência do Ambiente regulatório no Brasil}

Entre os tópicos e questões prementes discutidas durante a etapa de workshop e entrevistas, o ambiente regulatório foi largamente referenciado por participantes de todos os setores, houve comentário de que o órgão responsável no país, a ANVISA, atua de forma 
neutra, porém na grande maioria, os comentários, principalmente por parte de startups e empresas, demonstram que estas consideram que a agência tem influenciado de forma negativa para a inovação do setor no país. Destacamos abaixo o resumo de alguns comentários feitos por representantes de startups:

$\checkmark$ A ANVISA não possui um ambiente regulatório adequado para startups;

$\checkmark$ Dificuldade no lançamento de novos produtos no mercado desenvolvidos inteiramente no Brasil;

$\checkmark$ Existência de entraves regulatórios que impedem parcerias entre instituições, em especial aquelas necessárias para condução de pesquisa clínica;

$\checkmark$ As regras da ANVISA são complexas e não diferencia startup de grandes empresas farmacêuticas, impões exigências que inviabilizam o desenvolvimento de startups principalmente na fase inicial e impactando negativamente no desenvolvimento de negócios para o setor no país.

Na experiência e visão de integrantes de empresas estabelecidas, foram destacados pontos como:

$\checkmark$ Avanços na legislação, como o Marco Legal da Inovação, esbarra em limitações do regime jurídico no qual empresas públicas se enquadram;

$\checkmark$ Dificuldade de aprovação de registro e preço de produto por parte do regulatório;

$\checkmark$ Necessidade de atenção direcionada para o ecossistema em torno da cadeia produtiva, principalmente investimentos no regulatório, políticas públicas e inovação;

$\checkmark$ Morosidade na resposta por parte da agência sobre produtos que não são relacionados à covid-19;

$\checkmark$ Alegam que o ambiente regulatório quase que pune quem inova no Brasil, não incentivam a inovação no país, principalmente relacionado a precificação final do produto que não considera a tecnologia, desvalorizando o esforço inovativo;

Destaque para o comentário feito por um representante de uma das pouquíssimas empresas nacionais de biotecnologia. 
Existe no Brasil leis que "quase proíbem" inovação, por exemplo, uma lei de 1958, mais de 60 anos, que limita a dedutibilidade de royalties no desenvolvimento de medicamentos, é preciso licenciar vários componentes da sua invenção, a exemplo de uma vacina, você precisa adjuvante, você vai precisar de alguns incipientes, as vezes vai precisar de alguma delivery system, etc. nessa área é facilmente ter custos de $20 \%$ no produto final, pagando royalties, o Brasil é o único país do mundo que isso não é considerado um custo, aí você vai ter um preço mais alto para o seu produto, simplesmente por causa de uma lei que "ninguém" quis modificar, segundo o especialista, essa é uma informação que já foi reportada para o nível de ministros, no próprio ministério da Fazenda, entretanto, nunca foi tomada atitude quanto ao assunto. O especialista complementa, então para mim, é um mito que o Brasil tem interesse em inovar, que a indústria tem interesse nisso, em ganhar dinheiro fácil, por que eu vou investir em inovar? Isso leva tempo, é complicado e tem essas outras coisas que inibem. Para mim, não iria existir se realmente tivesse interesse em inovar, é muito mais fácil no Brasil, importar, comprar e vender, é fácil e o país funciona assim., não funciona para inovação.

Para instituições, diferentemente das alegações feitas por membros de startups e empresas estabelecidas, houve consideração positiva em relação à agência, comentários como:

$\checkmark$ Afirma que é um mito que vem se colocando que a ANVISA é exigente demais. A ANVISA segue normas do US AID que é uma organização internacional que harmoniza as etapas e os espaços regulatórios no mundo todo. A nossa dificuldade é que não se tem uma cultura de atenção em relação as questões regulatórias que a mesma do FDA, EMA.

$\checkmark$ Existe ambiente regulatório já sedimentado no país, com leis claras que indicam, em matéria de direito administrativo, o rumo legal ao qual as empresas públicas $e$ privadas devem seguir. Entretanto, há falta de uma segurança jurídica para pôr em prática o que está previsto em lei. Além disto, há uma morosidade muito grande do processo legal, o que torna desgastante se adequar dentro das regras impostas;

$\checkmark$ Demora na aprovação do desenvolvimento de novas tecnologias pela Anvisa;

$\checkmark$ Os processos de inovação têm que se tornar cada vez mais interdependentes e colaborativos. As empresas e startups desenvolvem os seus produtos, mas tem um 
ciclo muito longo de desenvolvimento até chegar no mercado. O processo de validação de tecnologias é muito custoso

Portanto, mesmo sendo uma influência indireta, conforme apresentado Figura 2, em nível da indústria e da economia, na acumulação de capacidades tecnológicas, as políticas públicas e marcos regulatórios estão afetando de modo negativo no ambiente de negócios para a inovação no setor de biotecnologia para saúde humana no Brasil, o que demonstra a necessidade de investigar com certo grau de detalhe até que ponto e em qual medida essas "regras do jogo" precisam se adaptar à realidade das startups, que são totalmente distintas de grandes farmacêuticas e necessitam de incentivos não somente financeiros, mas de regulações que impulsionem essas nascentes atravessarem o "vale da morte" com auxílio e se tornarem empresas rentáveis para a economia da nação e para as empresas estabelecidas. Em conjunto, faz-se necessário aferir que melhorias nas políticas públicas podem reduzir reveses como a dificuldade de acesso, morosidade por parte da reguladora e, principalmente, a desvalorização dos investimentos feitos em inovação no país.

\subsection{Impressões com relação a Funding}

O termo Funding refere-se ao fomento à inovação realizados através de captação de recursos financeiros, seja através de investimentos por parte de agentes financeiros ou órgãos de fomento, seja por parte da iniciativa privada, que injeta recursos financeiros no desenvolvimento de novas tecnologias. As impressões dos representantes de startups, empresas e instituições com relação ao Funding no país é destacada abaixo nessas duas temáticas, financiamento da biotecnologia no país e investimentos em novas tecnologias.

\subsubsection{Financiamento da biotecnologia no país}

Devido aos altos custos e incertezas que permeiam a biotecnologia para saúde humana, a percepção dos participantes quanto ao tema, por parte das startups é que:

$\checkmark$ Agências de fomento investem na parte inicial da pesquisa, considerada a parte mais crítica, porém este investimento se perde quando há transferência de tecnologia para uma empresa grande, devido à ausência de parceria; 
$\checkmark$ O investimento para pesquisa e desenvolvimento (P\&D) é muito difícil para startups e empresas privadas, os investidores querem investir para escalar o negócio, mas não para fazer pesquisa;

$\checkmark$ O financiamento público é o elemento fundamental para o desenvolvimento da inovação tecnológica no país, isto porque, os custos envolvidos na pesquisa científica, atrelando-os a longos períodos para o retorno do investimento e a incerteza que paira sobre a pesquisa, tornam o investimento privado algo muito arriscado;

$\checkmark$ Dificuldade de inserir a tecnologia desenvolvida dentro da universidade no mercado, em função da falta de financiamento que viabilizem aumentar a escala de produção e a continuidade do processo de desenvolvimento tecnológico. Limitação dos recursos oriundos das FAPs, em especial aquelas situadas no nordeste do país, em função da falta de financiamento em ciência e tecnologia no país;

$\checkmark$ Falta de investidores no Brasil com investimentos voltados a startups, realidade diferente de países como Estados Unidos e Israel, que possuem fundos de investimentos voltados a este setor;

$\checkmark$ Falta de recursos de longo prazo para pesquisa. Recursos das FAPs não são complementares entre si, são direcionados a uma única finalidade, tais como: Equipamentos laboratoriais, insumos, recursos humanos, etc;

$\checkmark$ Falta de um investimento voltado a uma etapa de risco do desenvolvimento do produto, que compreenderia a saída da pesquisa de bancada até sua inserção no mercado. Grandes empresas farmacêuticas não querem financiar esta etapa devido ao alto risco envolvido;

$\checkmark$ Afirmou que não há apoio financeiro suficiente para financiamento da fase de testes clínicos, voltados aos laboratórios que querem empreender;

$\checkmark$ Os valores propostos pelas agências públicas de financiamento para pagamento de recursos humanos (bolsas) são muito baixos, frente as necessidades e especializações dos profissionais envolvidos. Relatou, também, que as agências de financiamento (FAPESP) não são auditáveis: Não possuem os mesmos prazos e regulações as quais os pesquisadores e empresas precisam preencher ao pleitearem recursos junto a esta agência; 
$\checkmark$ Relata que precisamos de um ambiente favorável para o investimento privado. Afirma ainda que as iniciativas em biotecnologia, precisam estar conectadas com o ambiente internacional;

$\checkmark$ Afirmou que existe pouco investimento em empresas e tecnologias criadas dentro do âmbito de universidades, empresas e instituições brasileiras;

$\checkmark$ Brasil ainda não tem um ambiente propício de mercado de investimentos, nessa área de Deep Science que é muito longo e que consome uma quantia de dinheiro considerável;

$\checkmark$ Necessário investidor de capital inteligente pois não temos muitos fundos de que investem em biotecnologia, há também a necessidade de colaboração públicoprivada;

Por parte das instituições, como ponto positivo, foram os comentários abaixo:

$\checkmark$ Existe na FAPERJ o edital de doutor empreendedor que apoia doutores que estão indo para o ambiente de inovação fundarem startups. Outro modelo de financiamento que tem é combinando recursos não reembolsável com recurso via crédito para projetos de inovação. A FAPERJ quer ter um foco especial no apoio ao complexo de saúde, especialmente em startups na área de biotecnologia humana. Vai investir aproximadamente 40 milhões nessa área e vai ter projetos em vacinas e covid, vacinas e tratamento;

$\checkmark$ Estados possuem agências de fomento com ênfase e capacidade financeira diferente, de forma que a FAPESP é capaz de investir mais e melhor se comparada a FAPERJ;

Como pontos de melhorias por parte das instituições, foram destacados os comentários abaixo:

$\checkmark$ Falta capital para financiar o que vai além da pesquisa. Os fundos de investimento, do BNDES, por exemplo, possuem um ciclo de captação e desinvestimento muito curtos que não são compatíveis com startup de saúde e acaba que falta no Brasil esse tipo de veículo de investimento de startups que estão fazendo o Deep tech;

$\checkmark$ Falta de continuidade nos mecanismos de fomento público na área da saúde; 
$\checkmark$ Necessidade de se fazer políticas públicas para que as empresas nacionais possam se unir;

$\checkmark$ Falta a participação do governo no incentivo ao desenvolvimento da biotecnologia no Brasil. Destaque para a escassez de empresas nacionais de biotecnologia no brasil.

$\checkmark$ Precisamos de mais linha de crédito para o desenvolvimento de matérias primas internamente;

Por parte das empresas estabelecidas, os comentários feitos sobre investimentos no setor foram:

$\checkmark$ Falta estratégia de acesso para os pacientes que precisam de medicamentos biotecnológicos;

$\checkmark$ Necessidade de políticas claras e de larga escala em fomento voltados para a inovação no Brasil. Políticas claras e transparentes que torne atrativo para as empresas trazer seu corpo técnico, especializado, para o país;

$\checkmark$ O Brasil é reconhecido por políticas de investimento de curto prazo, de forma que novos investimentos são altamente direcionados e escolhidos, dada a característica de retorno rápido. Além disto, se faz necessário um modelo de negócios melhor estruturado nas empresas iniciais que possam ser apresentadas ao board de uma empresa;

$\checkmark$ Investimentos na área de biotecnologia são massivos e de altíssimo risco. Empresas farmacêuticas de grande porte tem aversão ao risco e prezam por tecnologias em fases finais de desenvolvimento, no qual há uma ideia concreta sobre o produto e uma dimensão do risco empregado.

O termo Deep Tech, segundo Distrito (2021), é característico de um setor tecnológico que concentra negócios de base científica. Ainda no artigo, o especialista no assunto, Guy Perelmuter, revela que universidade, laboratório e centros de pesquisas são cruciais para o surgimento de startups Deep Techs. Já no relatório Europeu sobre o assunto, EUST (2021), especialistas afirmam que para receberem o rótulo de Deep Tech, as startups devem possuir simultaneamente riscos relacionados à ciência ou engenharia para realizar suas ideias e, risco de provar a demanda de mercado principalmente por que boa parte das assim chamadas 
Deep Techs possuem características de inovações radicais, ou Breakthrough. Ainda em EUST (2021, p. 12) os especialistas mostram que startups Deep Techs e Biotechs possuem características de retorno do investimento em longo prazo e julgam ser relevante para mitigar o risco que elas tenham forte suporte de múltiplas direções como Venture Capital, Corporações, Academia e Governo.

Outro destaque importante sobre o tema financiamento, que será explorado com certo grau de detalhe nas próximas etapas da pesquisa, é sobre a presença de investimentos privados no país, principalmente direcionados a startups de biotecnologia para saúde humana.

\subsubsection{Investimento em novas tecnologias}

Complementar ao termo sobre financiamento, foram elaboradas questões para discussão entre os participantes sobre o investimento em novas tecnologias, as startups comentaram que:

$\checkmark$ Existem lacunas na indústria nacional em imunobiológicos, métodos de diagnóstico no sistema de saúde para tratar adequadamente e no tempo correto determinadas doenças.

$\checkmark$ Falta no país uma política de investimento em novas tecnologias de forma mais robusta, temos apenas iniciativas importantes na FAPESP e FAPERJ. Falta algo mais contundente, planejado, de longo prazo do governo federal ou do Ministério da Ciência, Tecnologia e Inovação-MCTI.

$\checkmark$ Transformar o conhecimento existente na bancada em produto de mercado é o grande desafio do país, falta conexão e sinergia entre as partes;

$\checkmark$ Existe um grande entrave cultural para aprovação de tecnologia brasileira, prevalece a tecnologia estrangeira;

As instituições trazem uma percepção que corrobora com as startups quanto à prevalência de conhecimento estrangeiro frente ao nacional, entre outros pontos, como:

$\checkmark$ Falta política pública para valorizar a tecnologia desenvolvida no Brasil;

$\checkmark$ Falta de políticas públicas de longo prazo, políticas de Estado consistentes e que não flutuem conforme mudanças no governo. 
$\checkmark$ Há uma aversão muito grande ao risco no Brasil, além da falta de visão de longo prazo, isso faz com que grandes empresas prefiram gastar mais terceirizando a pesquisa fora do país;

$\checkmark$ Há uma dificuldade de avançar para fases posteriores (fase 2,3,4) de uma nova molécula em função da falta de fomento exclusivo para esta área. Pesquisadores em universidades públicas precisam se dedicar a manter os programas de pós-graduação e a publicação de artigos, de forma que não conseguem ênfase na continuidade do desenvolvimento de um produto biotecnológico.

A contribuição por parte de empresas estabelecidas foi relacionada à falta de continuidade nos investimentos:

$\checkmark$ Investimentos nas fases de testagem de fármacos, por exemplo, constituem um grande gargalo dado o alto grau de investimento inerente a cada uma das fases $(1,2,3$ e 4), que envolvem grandes equipes médicas e centro especializados. Muitas pesquisas tendem a acabar justamente nesta fase.

\section{Análise dos resultados parciais}

Os resultados parciais das evidências coletadas até o momento demonstram que a biotecnologia é estratégica para o país, que o conhecimento está sendo gerado nas universidades e institutos de pesquisa. Porém, quando se trata de desenvolvimento tecnológico relacionado à biotecnologia para saúde humana, os custos são elevadíssimos, os riscos, acentuados e os prazos mais longos, não tão ágeis como vistos em plataformas digitais, tecnologias da informação e comunicação (TIC). Apostar em ciência é um processo árduo, requer investimentos público e privado, consistências nas políticas públicas e principalmente maior sinergia entre os atores envolvidos no ecossistema de inovação do país para que os avanços nessa área possam contribuir não apenas para o fortalecimento do SUS, mas que, consecutivamente, as empresas e startups consigam amadurecer os negócios oriundos dos conhecimentos desenvolvidos dentro da academia e acumular capacidade tecnológica inovadora para se tornarem referências no setor de biotecnologia para saúde humana mundialmente. 
Entre os desafios inerentes à pesquisa já apresentados no começo deste artigo, e reconhecida a importância da biotecnologia para o SUS e para a economia do país, identificar se há uma escassez de empresas e startups de biotecnologia no brasil, como essas corporações estão realizando esforços para acumular capacidade tecnológica, quais são as fontes para esse acúmulo e, principalmente, quais os impactos em termos de atividades inovadoras e competitividade são apresentados por elas, são aspectos que essa pesquisa elucidará. Com isso, buscamos contribuir para a construção de um sistema de monitoramento contínuo de indicadores de inovação e competitividade nesse tipo de indústria altamente dependente de ciência, tecnologia e inovação, que a metodologia aplicada com base em evidências e análise irá fornecer ao país e poderá contribuir significativamente com avanços em termos de políticas públicas e estratégias empresariais.

Afinal, quantas startups e empresas realmente são, stricto sensu, de biotecnologia para saúde humana no Brasil? Dessas existentes, elas possuem capacidades reveladas ou capacidades latentes represadas por deficiências internas ou lacunas no ecossistema brasileiro? Quais são as inovações realizadas por elas? E seus impactos estão sendo percebidos no país ou no mundo?

Esses são alguns aspectos que a pesquisa objetiva responder. O estudo prossegue e está previsto para ser finalizado em maio de 2022.

\section{Referências}

BRASIL. Lei No 9.787, de 10 de fevereiro de 1999. Dispõe sobre a vigilância sanitária, estabelece o medicamento genérico, dispõe sobre a utilização de nomes genéricos em produtos farmacêuticos e dá outras providências. Congresso Nacional, Brasília, DF, 11 fev. 1999. 
Lei $\mathrm{N}^{\circ}$ 13.243, de 11 de janeiro de 2016. Dispõe sobre estímulos ao desenvolvimento científico, à pesquisa, à capacitação científica e tecnológica e à inovação. Congresso Nacional, Brasília, DF, 12 jan. 2016.

Parcerias para o Desenvolvimento Produtivo (PDP). Ministério da Saúde, Brasília, DF, 08 mar 2021. Disponível em: < https://www.gov.br/saude/pt-br/assuntos/complexoindustrial-da-saude/instrumentos-estrategicos/pdp>. Acesso em: 19 de Nov de 2021.

CB INSIGHTS. The Complete List Of Unicorn Companies, 2021. Disponivel em: <https://www.cbinsights.com/research-unicorn-companies>. Acesso em: 22 de Nov de 2021.

EUST - EUROPEAN STARTUPS. 2021: the year of Deep Tech. Disponivel em: <https://dealroom.co/uploaded/2021/04/EUST-Dealroom-Sifted-Deep-Tech-Jan2021.pdf?utm_source=the+shift+newsletter\&utm_campaign $=a 43 f 2 c 979 c-$ the_shift_fp_2021_01_21\&utm_medium=email\&utm_term=0_7f93052ef8-a43f2c979c403080964>. Acesso em: 19 de Nov de 2021.

Distrito. Deep Tech Report 2021 - Um olhar sobre o ecossistema de inovação e novas tecnologias. Disponível em: < https://materiais.distrito.me/deep-tech-2021>. Acesso em: 29 de Out de 2021.

FDA. Food \& Drug Administration. Disponível em: <https://www.fda.gov/>. Acesso em: 17 de Nov de 2021.

FERREIRA, Maria C. Z., Teixeira, Clarissa S. Núcleo de inovação tecnológica: Alinhamento conceitual [recurso eletrônico]. - Florianópolis: Perse, 17p.: il. 2016. 1 e-book. Disponível em: <http://via.ufsc.br/>. Acesso em: 19 de Nov de 2021.

FIGUEIREDO, P. N. Gestão da inovação: conceitos, métricas e experiências de empresas no Brasil. 2. ed. Rio de Janeiro: LTC, 2015.

Fundamentos de inovação e de capacidade tecnológica. Santo André, 2019. MBA em Gestão da Inovação e Capacidade Tecnológica - Fundação Getúlio Vargas.

HUPFFER, Haide M., Berwig, Juliane A. A tecnologia CRISPR-CASg: da sua compreensão aos desafios éticos, jurídicos e de governança. Revista de Ciências Jurídicas - Pensar, v. 25 n. 3 (2020). Disponível em: < https://doi.org/10.5020/2317-2150.2018.9722>. Acesso em: 17 de Nov de 2021.

IPEA - INSTITUTO DE PESQUISA ECONÔMICA APLICADA. Medicina de precisão: fatores determinantes para seu aparecimento e crescimento. Brasília: Ipea, 2020. Disponível em: https://www.ipea.gov.br/cts/pt/central-de-conteudo/artigos/artigos/103-medicina-deprecisao-fatores-determinantes-para-seu-aparecimento-e-crescimento>. Acesso em: 24 de Nov de 2021. 
OCDE. Organização para a Cooperação Econômica e Desenvolvimento. OECD Biotechnology Statistics. 2009 Edition.

OMS. Organização Mundial da Saúde. Noncommunicable diseases - progress monitor 2020.

PERELMUTER, Guy. Future Presente: o mundo movido à tecnologia. Jaguaré, 2019. Companhia Editora Nacional.

UZIEL, D.; PIRES, C.; GOMES, C. V. S.; VEIGA, C. VIOLA, A. C. Identificação das Lacunas Tecnológicas e de Mercado em Biotecnologia para a Saúde Humana. Rio de Janeiro, 2018. PROINTER BIOTEC - SEBRAE. 